\title{
EQUAL PROTECTION, CLASS LEGISLATION, AND SEX DISCRIMINATION: ONE SMALL CHEER FOR MR. HERBERT SPENCER'S SOCIAL STATICS $\dagger$
}

\author{
Mark G. Yudof*
}

The Fourteenth Amendment: From Political Principle to Judicial Doctrine. By William E. Nelson. Cambridge, Mass.: Harvard University Press. 1988. Pp. ix, 253. $\$ 25$.

Freedom being the prerequisite to normal life in the individual, equal freedom becomes the prerequisite to normal life in society.

- Herbert Spencer, Social Statics ${ }^{1}$

Eclecticism in law and philosophy is rarely in fashion, ${ }^{2}$ for instinctively many scholars strive for the systematic and universal, the would-be-conquerors of the diversity of history and ideologies and cultural particularism. And the hedgehogs, to borrow from Isaiah Berlin, ${ }^{3}$ frequently command great respect from the foxes. It seems admirable that the hedgehogs seek to abstract the universal from the diverse and mundane, to perceive an interconnectedness amid the apparent disarray and chaos. But the pursuit of Occam's razor also may distract a scholar and distort reality. As Grant Gilmore warned in The Ages of American Law, "the lesson of the past two hundred years is that we will do well to be on our guard against all-purpose theoretical solutions to our problems."4

Profesșor William E. Nelson ${ }^{5}$ may be counted among the foxes. In his excellent book. The Fourteenth Amendment, he declines to succumb to the temptation of conceptual unity for its own sake, for he prefers the messiness of historical accuracy. Professor Nelson's pri-

$\dagger$ (C) 1990 by Mark G. Yudof.

* Dean and James A. Elkins Centennial Chair in Law, School of Law, The University of Texas at Austin. B.A. 1965, LL.B. 1968, University of Pennsylvania. - Ed. I wish to express my appreciation to Douglas Laycock, Sanford Levinson, and Scot Powe for their many suggestions and criticisms.

1. H. SPENCER, Social Statics 106 (1865).

2. But see M. Walzer, Spheres of Justice: A Defense of Pluralism and Equality 4-6 (1983); Shiffrin, Liberalism, Radicalism, and Legal Scholarship, 30 UCLA L. REv. 1103 (1983).

3. I. Berlin, The Hedgehog and the Fox (1953).

4. G. Gilmore, The Ages of American LAW 109 (1977).

5. Professor of Law, New York University. A.B. 1962, Hamilton College; LL.B. 1965, New York University; Ph.D. 1971, Harvard University. 
mary insight is that the equal protection clause of the fourteenth amendment represents a complex, multifaceted concept, drawing on a number of distinct historical and intellectual traditions. The urge to identify a single animating philosophy or an overarching theory of equal protection is understandable but misguided. ${ }^{6}$ And for Nelson it is not just a question of multiple meanings of the text (p. 61) - the interpretative philosophy or hermeneutics, as the cognoscente would urge. ${ }^{7}$ The framers of the Civil War amendments were eclectics in the best sense, drawing, perhaps naïvely and inconsistently, on natural rights, ${ }^{8} \mathrm{Jacksonian}$ democratic principles, ${ }^{9}$ abolitionism, ${ }^{10}$ state constitutional provisions, federalism, and other intellectual currents of the time. ${ }^{11}$ As Professor Nelson notes, "Whatever the reality, a popular ideology of liberty and equality existed in antebellum America. This mid-nineteenth-century ideology, from which section one of the fourteenth amendment was ultimately derived, had an amorphous quality that imprecisely linked together several ideas, each with a different core content" (p. 13; footnote omitted).

The urge to stand on the shoulders of the framers or framing generation is virtually irresistible. ${ }^{12}$ But the unhappy truth - at least for those who seek definitive guidance from the past - is that the nineteenth-century mind was no more orderly, precise, consistent, or clear than the twentieth-century mind.13 As Professor Nelson puts the point, with some irony, "it was the very emptiness and vagueness of the concept [of equality] that made it so useful and popular. Equality could mean almost anything ..." (p. 21).

For better or worse, the equal protection clause represents a reservoir of concepts. ${ }^{14}$ This does not mean that the clause is infinitely elastic or that any level of judicial activism or restraint is excused. ${ }^{15}$ Nor does it suggeśt that the modern anachronists are necessarily vindicated, as they perceive twentieth-century ideology in the prescient

6. See generally Soifer, Protecting Civil Rights: A Critique of Raoul Berger's History, 54 N.Y.U. L. REV. 651 (1979).

7. See generally INTERPRETING LAW AND LITERATURE: A HERMENEUTIC READER (S. Levinson \& S. Mailloux eds. 1988); Grey, The Constitution as Scripture, 37 STAN. L. REv. 1 (1984).

8. See, eg., J. TENBRoEK, EQUAL Under LAw 21 (1965); Farber \& Muench, The Ideological Origins of the Fourteenth Amendment, in 1 CONST. COMMENTARY 235 (1984); Soifer, supra note 6, at 659-65.

9. See generally E. Foner, Free Soll, Free LABor, Free Men (1970).

10. Id.

11. See generally H. HymaN \& W. Wiecex, EQUAL Justice Under LAw (1982); Tussman \& tenBroek, The Equal Protection of the Laws, 37 CALIF. L. REv. 341 (1949).

12. See R. Nisbet, History OF THE IdEA OF PROGRESS (1980).

13. See generally Farber \& Muench, supra note 8, at 241-46.

14. See H. Graham, Everyman's Constitution (1968).

15. See Kay, The Equal Protection Clause in the Supreme Court 1873-1903, 29 Buffalo L. REV. 667 (1980). 
minds of the nineteenth century. But it does suggest some care in disentangling the various threads of the idea of equality embodied in the fourteenth amendment, some recognition that conflicts among competing concepts may be inevitable, and some humility in asserting that one vision dictates its meaning. Justice Stevens' assertions notwithstanding, ${ }^{16}$ perhaps there is more than one equal protection clause.

Uncharitable though it may be to say so, the antislavery Republicans who framed the equal protection clause "were not original thinkers," and they thought of themselves as "guardians of the original American tradition, not as inventors of a novel ideology."17 One source of that tradition was the Enlightenment and the naturalistic theories that emerged in the seventeenth and eighteenth centuries and informed the Declaration of Independence. ${ }^{18}$ The concept of a higher law, Nelson suggests, embraced the claim "that God or nature required that people and their governments behave in particular ways" (p. 23). Another aspect of the American tradition asserted that citizens had inherent rights that derived from the nature and form of a republican political and social system (p. 24). These arguments were often "a form of political rhetoric occasionally addressed to courts but more frequently addressed to legislative bodies or to the people themselves" (p. 23).

The 1860 Republican platform specifically reaffirmed the natural law elements of the Declaration of Independence. ${ }^{19}$ In this view, people are equal in the sense of having an equal right to the state's protection of their natural freedoms. ${ }^{20}$ Blacks possess such natural rights, and they are entitled to the full or equal protection of the law in asserting them. ${ }^{21}$ In that sense, the equal protection clause is a corrective measure that seeks not to create new rights but to guarantee the protection of already existent rights of African-Americans that were being disregarded by state governments. ${ }^{22}$ The most obvious manifestation

16. Craig v. Boren, 429 U.S. 190, 211 (1976) (Stevens, J., concurring).

17. Farber \& Muench, supra note 8, at 241.

18. Id. (citing 3 . Locke, The SeCond TREATISE OF Civil Government 5 (J. Gough ed. 1946)).

19. Id. at 249. See generally E. FONER, supra note 9, at 75-76, 290.

20. See J. TENBRoek, supra note 8, at 21. See generally N. MACCoRMick, Legal RiGHTS AND Social Democracy 60-83 (1982).

21. See E. FonER, supra note 9, at 290-95; Maltz, The Concept of Equal Protection of the Laws - A Historical Inquiry, 22 SAN DIEGO L. REV. 499 (1985); Maltz, Fourteenth Amendment Concepts in the Antebellum Era, 32 AM. J. LEGAL HIST. 305 (1988).

22. See T. Cooley, A Treatise on the Constitutional Limitations Which Rest UPON THE LEgislative Power OF THE STATES OF THE AMERICAN UNION 466 (3d ed. 1874); see also Farber \& Muench, supra note 8, at 269; Soifer, supra note 6, at 701. 
of natural law theory is the 1866 Civil Rights Act, ${ }^{23}$ providing that blacks have the same rights as whites to enter into contracts, to own property, to sue, and to testify - in other words to invoke the protections of the legal system with regard to their civil or natural rights. ${ }^{24}$

This concept of the full protection of natural rights admits of a pluralistic vision of justice akin to Michael Walzer's theory of "spheres of justice."25 Equality in one sphere may co-exist with inequality in another. For example, Lincoln believed in constitutional equality of civil and personal rights for African-Americans but he was opposed to the extension of suffrage to them. Economic equality would follow only if blacks took advantage of their legal rights to improve their conditions (pp. 19-20). Other proponents of equality believed that inequality of wealth and social and political rights might co-exist with equality of civil or natural rights (p. 19). Their naive assumption was that the spheres can be separated, that inequalities in one domain will not spill over into another.

The other natural law vision of equal protection drew on the social contract theories of seventeenth-century philosophers like Locke and Stair. Political authority can be justified and there is a duty to obey the law only if there is a contract among the members of a community - with no member having superiority over any other member. ${ }^{26}$ People are equal in the sense of each person's voluntary consent counting equally, though they may not be equal in talents, virtue, status, or wealth. This theory is consistent with Kant's insistence on a morality premised on respect for persons and treating each individual as a kingdom of ends, but it primarily reflects the idea that the legitimate exercise of power is predicated on the consent of the governed. Equality of this sort defines the concept of citizenship. ${ }^{27}$ From this perspective, the fourteenth amendment can be viewed as repudiating the Dred Scott decision ${ }^{28}$ and its impoverished view of black citizenship. ${ }^{29}$

Whatever the natural law background of the fourteenth amendment, there is universal recognition that a fundamental purpose of the framers was to address racial discrimination in the post-Civil War period:

The Republican proponents of the Fourteenth Amendment all agreed that race was not a legitimate reason to treat people differently in respect to their civil rights - that a black man and a white man, even though

23. Ch. 31, § 1, 14 Stat. 27 (1866) (current version at 42 U.S.C. § 1981 (1988)).

24. See generally R. BERger, Government by Judiciary: THE TRansformation of THE FOURTEENTH AMENDMENT 169-70 (1977); Soifer, supra note 6, at 705.

25. M. WALZER, supra note 2.

26. See generally N. MACCoRMick, supra note 20.

27. See Slaughter-House Cases, 83 U.S. (16 Wall.) 36, $95-98$ (1872) (Field, J., dissenting).

28. Scott v. Sandford, 60 U.S. (19 How.) 393 (1857).

29. See generally E. FONER, supra note 9, at 261-300. 
they occupied a different socio-economic position, must receive the same treatment from the law. [p. 89]

The equal protection clause thus embraces a specific conception of racial justice - one that may permit protective measures in the transition from slavery to freedom ${ }^{30}$ even as it aspires to a more global concept of constitutional equality. And in the modern context, extensions of equal protection doctrine to other groups increasingly have depended on extrapolating from the circumstances of AfricanAmericans. ${ }^{31}$

But nineteenth-century Americans, like their eighteenth-century counterparts, were not content to protect liberty only through the provision of rights. In Madisonian fashion, they believed that liberty requires the proper governmental structure. However ironic it may appear more than one hundred years later, the framers of the fourteenth amendment also were concerned with "federalism as a bulwark of liberty" (p. 27). Opponents of the amendment routinely invoked the specter of domination by the federal government and the diminution of state power (p. 111). Far from accepting such criticism, the proponents bridled and went to great lengths to rebut the argument. They argued that the Southern states would quickly comply with the amendment, thereby obviating the potential conflict with the national government (p. 111), that Congress would be the primary enforcer of the amendment and would respect states' rights (p. 112), and that "[t]he only effect of the amendment was to prevent the states from discriminating arbitrarily between different classes of citizens" ( $p$. 115). The last argument is the most interesting, for it undercuts natural law theories. It is predicated on the assumption that the fourteenth amendment did not create new rights, but only addressed the unequal treatment of classes of persons with respect to those rights that the states chose to recognize.

To perceive the importance of any one of these three strands of equal protection - and I will soon add a fourth - is not to deny the importance or relevance of the other strands. That is the essence of Nelson's careful approach to constitutional history. But the modern interpreter of the equal protection clause should be wary, for the multiple historical roots of the fourteenth amendment breed complexity and confusion. This is particularly true, as Professor Nelson points out, because the framers did not view themselves as involved in the task of delineating a logical and coherent set of legal doctrines for application in concrete cases:

Those who used the discourse of equality, natural law, natural rights, and federalism in the three decades before the Civil War generally were

30. See Soifer, supra note 6.

31. See J. Ely, Democracy AND Distrust (1980). 
not concerned with intellectual coherence or precision, but with persuading those to whom their rhetoric was addressed ....

Ultimately, the adoption of the Fourteenth Amendment would require the transformation of this political rhetoric .... into legal doctrine. ... But the congressmen and state legislators who had been schooled in the imprecise modes of antebellum thought did not transform their discourse overnight. They continued to make fuzzy use of the old antebellum ideas, in part, perhaps, because the old imprecision had the same value to them during Reconstruction that it had before the Civil War: it enabled them to retain the support of political coalitions whose individual members shared an agreement only about vague ideas, not about specific programs. [pp. 36, 38-39; citation omitted]

In this light, it is a mistake to assess the fourteenth amendment as if it were a conventional example of lawmaking. Rather, as Professor Nelson suggests, it is far more accurate to understand the fourteenth amendment as a "peace treaty to be administered by Congress," a treaty that embodied conflicting and ambiguous antebellum "hopes for a just society" (pp. 110-11).

\section{II}

While there are many flowers (and perhaps a few weeds) in the equal protection garden, some flowers have received more appreciative gazes than others. In large measure, I attribute the neglect to a simple misperception: too many modern constitutionalists ignore the history of the Jacksonian concept of equal protection before it was transformed by the abolitionists and embodied in the fourteenth amendment. To correct this misperception, I wish to explore at length another facet of equal protection, a facet that thus far I have deliberately overlooked in Professor Nelson's splendid taxonomy. I then will apply the antebellum concept of equal protection, as refined in the fourteenth amendment, to the question of sex discrimination.

The fertile ground for our inquiry is deceptively simple and derived from Jacksonian and antislavery principles (pp. 13-21): the fourteenth amendment should guarantee equality under the law. ${ }^{32}$ As Representative John Bingham eloquently stated the idea, the equal protection clause declares "the absolute equality of all citizens of the United States politically and civilly before their own laws" (p. 78):

Your Constitution provides that no man, no matter what his color, no matter beneath what sky he may have been born, no matter in what disastrous conflict or by what tyrannical hand his liberty may have been cloven down, no matter how poor, no matter how friendless, no matter how ignorant, shall be deprived of life or liberty or property without due process of law - law in its highest sense, that law which is the perfection

32. See N. MACCORMICK, supra note 20. See generally F. HAYEK, THE Constitution of LiBerTy (1960); R. Nozick, ANARCHY, STATE, AND UTOPIA (1974). 
of human reason, and which is impartial, equal, exact justice. [p. 78; footnote omitted]

To state the principle more generally, the nineteenth-century notion of equality before the law was one of a normative order "which impartially and universally regulates the actions and relationships of legal persons" through general and abstract laws. ${ }^{33}$

Before proceeding to a more detailed analysis of equality under law, two preliminary observations are in order. First, the federal equal protection clause drew on earlier state constitutional provisions seeking similar objectives. The eminent nineteenth-century treatise writer Thomas Cooley said as much, urging that "it was not within the power of the States before the adoption of the fourteenth amendment, to deprive citizens of the equal protection of the laws . . . "34 It was only the unwillingness of many states to afford equal protection to freed blacks that occasioned the immediate need for the amendment (p. 79).

Second, the confusion surrounding the equal protection clause stems in part from a misunderstanding of the normative roots of equality under law. ${ }^{35}$ Such equality is not only a principle of formal justice; it also draws on a distinctly nineteenth-century concept of liberty. ${ }^{36}$ Equal protection affirms the autonomy and liberty of persons to order their own affairs, subject to general laws which do not create favored or disfavored classes of citizens. ${ }^{37}$ Equality refers to equality of freedom and not to equality in the sense of achieving distributive justice.

To comprehend this meaning of equal protection, one should begin with the language of the Constitution itself. The fourteenth amendment declares that a state may not "deprive any person of life, liberty, or property, without due process of law" or "deny to any person within its jurisdiction the equal protection of the laws."38 Equal protection of the laws is afforded to "any person," not just to blacks." While the equal protection clause was certainly designed to eliminate some or all forms of racial discrimination, ${ }^{40}$ it creates protections for

33. N. MACCoRMick, supra note 20 , at 7.

34. See T. COOLEY, supra note 22, at 466.

35. See generally H. MEyer, The History AND MEANING of THE FourteEnTH AMENDMENT (1977); Farber \& Muench, supra note 8; Kay, supra note 15.

36. See F. HAYEK supra note 32; H. SPENCER, supra note 1.

37. See F. HAYEX supra note 32, at 154.

38. U.S. CoNST. amend. XIV, $\$ 1$.

39. See generally H. GRAHAM, supra note 14; Laycock, Book Review, 59 TeXas L. Rev. 343 (1981) (reviewing J. Ely, DEMOCRACY AND DisTrust (1980)).

40. See J. TENBRoEk, supra note 8; Dimond, Strict Construction and Judicial Review of Racial Discrimination Under the Equal Protection Clause: Meeting Raoul Berger on Interpretivist Grounds, 80 Mich. L. REv. 462 (1982); Soifer, supra note 6. See generally H. BELz, A NEW BIRTH OF FREEDOM (1976); Frank \& Munro, The Original Understanding of "Equal Protection of the Laws", 1972 WASH. U. L.Q. 421. 
all..$^{41}$ Indeed, even pre-Civil War abolitionists understood the need for a more expansive approach to equality under law:

What ... began as a campaign for protection of slaves and free Negroes presently became one to guarantee civil liberties more generally. Obliged to defend even their rights to discuss slavery and to seek its overthrow by constitutional means, abolitionists focused intently on the problem of securing and enforcing constitutional rights. They were interested, not merely in their own rights, but also in those of other dissident and unpopular groups including Indians and Mormons. ${ }^{42}$

But if equal protection means something more than a substantive prohibition on racial discrimination, what exactly does it mean?

Consider the claim of Thomas Cooley, perhaps the most influential constitutional writer of the nineteenth century, that the principle of equal protection was embodied in the Constitution even before the fourteenth amendment was adopted:

It was not within the power of the States before the adoption of the fourteenth amendment, to deprive citizens of the equal protection of the laws; but there were servile classes not thus shielded, and when these were made freemen, there were some who disputed their claim to citizenship, and some State laws were in force which established discriminations against them. To settle doubts and preclude such laws, the fourteenth amendment was adopted; and the same securities which one citizen may demand, all others are entitled to. ${ }^{43}$

Cooley's analysis, put forward only a few years after the ratification of the fourteenth amendment, asserts that the amendment only clarified the application of an older principle of law to the newly emancipated slaves. Howard Graham, in his massive analysis of the history of the fourteenth amendment, agreed with Cooley's assessment nearly a hundred years later:

[T]he Fourteenth Amendment, like the Bill of Rights which the Fathers added to the original Constitution in 1791, was regarded by its framers and ratifiers as declaratory of the previously existing law and Constitution.

...

... [S]ection 1 [of the Fourteenth Amendment] blanketed the freedmen in; it couldn't and didn't throw others out. Application of these guarantees in defense of Negro and racial rights, in other words, was climatic, normative, additive, not original, unique, or exclusionary. $\mathrm{Ne}$ groes were to get what others long ago had had. That was the whole

41. See H. Graham, supra note 14, at 169; H. TAylor, Due Process of LAW and THe EQual Protection of THE LAws 48 (1917); Laycock, supra note 39.

42. H. GRAHAM, supra note 14 , at 169 (footnote omitted).

43. T. COOLEY, supra note 22, at 466; see also H. GRAHAM, supra note 14, at 299-300, 322 23. John A. Bingham, the Ohio Congressman who later was the primary draftsman of $\S \S 1$ and 5 of the fourteenth amendment, made much the same point in 1859. H. GRAHAM, supra note 14, at 283-84. See generally P. Paludan, A Covenant with Death: The Constitution, LAW, aNd EQUality IN THE CIVIL WAR ERA (1975). 
thought and point ....44

Thus, as Professor Nelson well understands, equal protection speaks not only to race but also to an underlying constitutional principle of nondiscrimination by class that includes the prohibition of racial discrimination (p. 133). It is broader than the narrow principle that the fourteenth amendment prohibits state-sponsored racism, deriving protection for other groups only by analogy (p. 180). These nonracial origins of the unequal treatment of classes under the equal protection clause, too often, have been ignored by twentieth-century courts and scholars, particularly as they rush to limit judicial review in cases arising in the economic sphere. ${ }^{45}$

\section{III}

The bedrock principle underlying the quest for equality under law is disarmingly simple: "every one has a right to demand that he be governed by general rules." 46 No class of persons is to be privileged. There are to be no castes of untouchables. That principle can be traced to varied sources, including the British political philosophers upon whose ideas the American Declaration of Independence is largely founded. Nineteenth-century court opinions make frequent reference to John Locke's maxim that those who legislate "are to govern by promulgated, established laws, not to be varied in particular cases, but to have one rule for rich and poor, for the favorite at court and the countryman at plough"; 47 Blackstone, Rousseau, even Cicero are relied upon for similar sentiments. ${ }^{48}$ The idea, of "equality before the law," advanced by Charles Sumner in 1849, looked back to the French revolutionary constitution of 1791: "Men are born and continue free and equal in their rights." 49 And English common law and statutes were hostile to domestic monopolies, monopolies that restricted the liberties of some merchants but not others. ${ }^{\text {so }}$

But the sources of this idea of equality are also found on this side of the Atlantic. The Declaration of Independence comes immediately to mind. So also do the provisions of the Constitution that bar granting titles of nobility, impairing contractual obligations, or enacting

44. H. GraHAM, supra note 14, at 299-300, 581 (emphasis added; footnote omitted); see also Farber \& Muench, supra note 8.

45. P. 200. See generally Benedict, Laissez-Faire and Liberty: A Re-Evaluation, 3 LAw \& HIST. REV. 293 (1985).

46. T. COOLEY, supra note 22 , at 459.

47. Id. (quoting J. Locke, LOCKE ON Civil GovernMENT $§ 142$ p. 459); see e.g., State v. Duffy, 7 Nev. 342,349 (1872).

48. See Frank \& Munro, supra note 40, at 436.

49. Id. (quoting C. SuMNER, 10 wORKS OF CHARLES SUMNER 282, 327 (1874)).

50. See, e.g., Darcey v. Allin, 77 Eng. Rep. 1260 (K.B. 1602); Davenant v. Hurdis, 72 Eng. Rep. 769 (K.B. 1599). See generally Conant, Antimonopoly Tradition Under the Ninth and Fourteenth Amendments: Slaughter-House Cases Re-Examined, 31 EmORY L.J. 785, 792-97 (1982). 
laws that apply after the fact or single out particular individuals for government attention - all of which go to confirm the belief that "all are equals in government." 51 For that reason, law must be general, and not particularized; future-looking, not retrospective. Five of the original thirteen states recommended that the proposed Bill of Rights forbid Congress from granting "exclusive advantages of commerce" to particular merchants or companies.52 Many nineteenth-century state constitutions insisted that legislatures proceed by general rather than special laws. ${ }^{53}$ Even in states whose constitutions did not specifically ban special legislation, courts relied on provisions such as "law-of-theland" clauses to require general laws, "equally binding upon every member of the community." 54

This concern with general laws, according to Professor F.A. Hayek, was the chief constitutional development of pre-Civil War America:

We find in discussions of the period constant references to the conception of "general laws, formed upon deliberation, under the influence of no resentment, and without knowing upon whom they will operate." There was much discussion of the undesirability of "special" as distinguished from "general" acts. Judicial decisions repeatedly stressed that laws proper ought to be "general public laws equally binding upon every member of the community under similar circumstances." Various attempts were made to embody this distinction in state constitutions, until it came to be regarded as one of the chief limitations upon legislation. ${ }^{55}$

51. See J. ElY, supra note 31, at 90-91; F. HAYEK, supra note 32, at 188; Corwin, The Basic Doctrine of American Constitutional Law, 12 MICH. L. REv. 247, 248-55 (1914).

52. Conant, supra note 50, at 800-01.

53. See T. COOLEY, supra note 22 , at $456-66$.

54. Durkee v. Janesville, 28 Wis. 464,470 (1871); cf. Bailey v. Illinois, 190 IIl. 28, 60 N.E. 98 (1901).

55. F. HAYEK, supra note 32, at 188 (footnote omitted). State supreme courts were generally not reluctant, except in volatile cases involving the treatment of blacks or other racial minorities, to overturn special legislation as in violation of state constitutions. For example, as early as 1814, the Supreme Judicial Court of Massachusetts, in refusing to uphold the suspension of a general law in favor of an individual, stated:

It is manifestly contrary to the first principles of civil liberty and natural justice, and to the spirit of our constitution and laws, that any one citizen should enjoy privileges and advantages which are denied to all others under like circumstances; or that any one should be subjected to losses, damages, suits or actions, from which all others under like circumstances are exempted.

Holden v. James, 11 Mass. 396, 404 (1814) (citations omitted). Similarly, Chancellor Kent, writing in 1816, opined that a law limited to public officials was unconstitutional since it was "not impartial in the imposition which it creates. If the principle be just, it ought to have a general and equal application." W. KENT, MEMOIRS AND LETTERS OF JAMES KENT, LL.D. 163 (1898). The Supreme Court of Wisconsin in 1860 stated that the legislature "cannot, under color of making laws to regulate and extend the boundaries of cities or villages, enact for the mere purpose of cutting off or reducing the exemptions of particular individuals, and thus legislate specially for it against certain persons, contrary to the spirit and intent of the constitution." Bull v. Conroe, 13 Wis. 260, 272-73 (1860). Judge Cooley cites numerous state court decisions to the same effect and synthesizes them into the following general rule:

[A] statute would not be constitutional which should proscribe a class or a party for opin- 
More recently, Professor Robert Gordon, writing from a political perspective very different from that of Hayek, concurred in his appraisal of nineteenth-century constitutional law: "[F]reedom and jural equality, regardless of status, are made to depend on the abstract, formally realizable, nondiscretionary, and above all general nature of legal principles." 56

The idea that laws should be general and not tainted by considerations of class or caste was widely recognized and accepted before the fourteenth amendment was enacted (pp. 13-21). It was part-and-parcel of the presumed fairness of governmental processes, ${ }^{57}$ of due process of law. When Cooley argued that the states were not free to deny the equal protection of the laws even before the adoption of the Civil War amendments, he was generally drawing on due process notions. He presumably meant that state due process, equal protection, special legislation, and other constitutional clauses had implicitly or explicitly forbidden "special" or "class" legislation, and his treatise devoted most of its section on impartial legislation to developments in the states prior to the adoption of the fourteenth amendment. ${ }^{58} \mathrm{He}$ made only fleeting references to the newly enacted equal protection clause.

President Jackson, in his veto message on the second national bank, also had stressed that the law should not add "artificial distinctions" by seeking "to grant titles, gratuities, and exclusive privileges, to make the rich richer and the potent more powerful." $59 \mathrm{He}$ first advanced the phrase "equal protection" in 1832, almost forty years before it was written into the Constitution:

ion's sake, or which should select particular individuals from a class or locality, and subject them to peculiar rules, or impose upon them special obligations or burdens, from which others in the same locality or class are exempt.

T. COOLEY, supra note 22 , at $457-58$.

56. Gordon, Legal Thought and Legal Practice in the Age of American Enterprise, 1870-1920, in Professions AND Professional Ideologies in AMERICA, 1730-1940, at 90 (G. Geison ed. 1983).

57. The notion of fair procedures included the requirement that the law be the same for all, that it subject different persons to the same rules for vindicating entitlements and resolving disputes. See Durkee v. Janesville, 28 Wis. 464 (1871). As Cooley quotes an 1825 Maine Supreme Court decision:

On principle it can never be within the bounds of legitimate legislation to enact a special law, or pass a resolve dispensing with the general law in a particular case, and granting a privilege and indulgence to one man, by way of exemption from the operation and effect of such general law, leaving all other persons under its operation. Such a law is neither just nor reasonable in its consequences. It is our boast that we live under a government of laws, and not of men; but this can hardly be deemed a blessing, unless those laws have for their immovable basis the great principles of constitutional equality.

T. Cooley, supra note 22, at 459 n.2 (quoting Lewis v. Webb., 3 Me. 326, 336 (1825)). Or, as Daniel Webster urged in his famous argument in the Dartmouth College Case, a legislative enactment must be a general law if it is "to be considered the law of the land." Trustees of Dartmouth College v. Woodward, 17 U.S. (4 Wheat.) 518 (1819).

58. T. COOLEY, supra note 22, at 456-66.

59. J. Pole, The Pursurt of Equality in AmERican History 145 (1978) (quoting Jackson). 
There are no necessary evils in Government. Its evils exist only in its abuses. If it would confine itself to equal protection, and, as Heaven does it showers its favor alike on the high and the low, the rich and the poor, it would be an unqualified blessing. ${ }^{60}$

This substantive view of equal protection was rooted, in part, in a due process conception of the separation of legislative and judicial powers. Due process required that legislative bodies enact general laws, that they legislate for all citizens. ${ }^{61}$ Legislatures were not to enact laws that benefited or harmed particular classes and individuals in a predictable manner. ${ }^{62}$ Conversely, "judicial and quasi-judicial officers regularly and legitimately make decisions about individuals."63 Due process, then, meant different things for different branches of government. Legislatures are not required to give notice of pending legislation to affected parties, nor must they listen to such parties. But legislatures must enact general laws, laws that do not create classes of disfavored citizens (p. 180). Judicial bodies were to provide each person with the process that was due in applying abstract laws to specific persons. Here due process did require notice and a meaningful opportunity for the individual to be heard. ${ }^{64}$ In this sense, the equal protection clause did little more than affirm a structural vision of due process, ${ }^{65}$ an affirmation necessitated by the mistreatment of AfricanAmericans by state governments.

The difficulty of elaborating this principle of equal protection resides in defining what one means by a general law and then applying that definition to concrete cases. The framers of the fourteenth amendment faced two critical issues that continue to plague fourteenth amendment analysis to this day:

The first one, once they moved beyond obviously defective racial criteria, was to distinguish classifications that would be reasonable under the amendment from those that would be arbitrary. The second one was whether legislation which classified people on both reasonable and arbitrary grounds should be declared unconstitutional. [p. 138]

But, while they discussed equality under the law at length, the framers

60. Id. (emphasis added).

61. See Laycock, supra note 39 , at 372.

62. F. HAYEK, supra note 32 , at 210 . Justice Stevens has made a similar point:

All general laws - whether designed to protect the health of the community, to control urban traffic, to improve the environment, or to raise tax revenues - curtail the individual's freedom to do as he pleases. .... Ordinarily the mere fact that the existence of a general regulation may significantly impair individual liberty raises no question under the Due Process Clause. But the Clause is implicated when the State singles out one person for adverse treatment significantly different from that imposed on the community at large.

Hewitt v. Helms, 459 U.S. 460, 48485 (1983) (Stevens, J., dissenting) (footnote omitted). See generally Michelman, Politics and Values or What's Really Wrong with Rationality Review?, 13 CREIGHTON L. ReV. 487, 496-98 (1979).

63. Laycock, supra note 39 , at 372 .

64. Id.

65. Cf. Unger, The Critical Legal Studies Movement, 96 HARv. L. REv. 561 (1983). 
rarely attempted to connect general principles to concrete applications (p. 144).

When the framers did attempt to explain the meaning of equality under the equal protection clause, their explanations often were not particularly enlightening. For example, Professor Nelson quotes from a congressional speech by Senator Richard Yates in which Yates attempted to illuminate the distinction:

To define the length of residence necessary to enable a man to vote, to say what his age shall be, is one thing; and to say that he shall not vote at all because he is black or white, is an entirely different thing. In the latter case, color is made the disqualification, just as race would be if Germans were excluded from the ballot-box. The State may preserve a right; it may fix the qualifications; it may impose certain restrictions so as to have that right preserved in the best form to the people; but it is not legitimately in the power of the State, it is not in the power of the Congress of the United States, it is not in any earthly power to destroy a man's equal rights to his property, to his franchise, to his suffrage, or to the right to aspire to office - I mean according to the true theory of a republican government. [p. 83; citation omitted]

But while Senator Yates gives an example of class legislation, beyond all "earthly power," and of a reasonable classification (though the modern Supreme Court disagrees), ${ }^{66}$ he gives not a hint as to what is the conceptual basis of the distinction. Ultracrepidarian rhetoric simply substitutes itself for theoretical clarity.

The framers' inability to articulate a theory of class legislation may be explained by the inherent difficulty of the problem; philosophers have debated the meaning of equality for many centuries. But Professor Nelson argues that the absence of a coherent theory of equality is not just an accident or a function of the intractability of the intellectual puzzle; rather, it is also a testament to the political realities of the time:

[M]ost of the rhetoric of equality preached by the Republican supporters of the Fourteenth Amendment never went beyond vague generalities. . . . Republicans agreed that all people, including blacks, were entitled to equal rights. However, an element of the agreement - an element essential to creating the supermajorities need to incorporate the equal protection concept into the Fourteen Amendment - was its ultimate emptiness. Americans of 1866, like Americans of today, could agree upon the rightfulness of equality only because they did not agree on its meaning, and their political leaders, unlike the managers of the modern bureaucratic state, were content to enact the general principle rather than its specific applications into law. [p. 80; footnote omitted]

Thus the critical questions of equal protection analysis - which classi-

66. See, e.g., Dunn v. Blumstein, 405 U.S. 330 (1972) (one-year residency requirement for voting declared unconstitutional). 
fications of persons run afoul of equal protection and why do they do so - were rarely answered by the framers.

To discern the meaning of equality under the fourteenth amendment, one must begin with a recognition that slavery and race were the driving forces of conceptual disharmony during the first half of the nineteenth century. ${ }^{67}$ President Jackson's vision of equal protection extended only to social and economic barriers and was influenced by the traditional abhorrence of state-created monopolies; 68 its application to blacks "would have astounded Jackson, who would assuredly have disapproved."69 But sometimes powerful ideas drift across ideological barriers; ${ }^{70}$ they become serviceable in the aid of new causes, though the transition may cause confusion. Such a drift occurred in nineteenth-century America. Professor Eric Foner ably describes this phenomenon as many Jacksonian Democrats moved from a focus on "banks, monopolies, and paper money" ("Money Power") to a focus on slavery and the South ("Slave Power"). ${ }^{71}$ Consider Foner's portrayal of Senator Thomas Morris, a leading anti-slavery Jacksonian Democrat:

In 1838 and 1839, Morris ... astounded the Senate and electrified antislavery northerners by declaring that a new power, based on slavery, was threatening the liberties of the nation. . . . He [later] pledged to devote his energies to the cause of emancipation, "and against the power of these two great interests - the slave power of the South, and banking power of the North - which are now uniting to rule this country." ... $[\mathrm{H}] \mathrm{e}$ warned that, just as with the Bank, the people would mobilize against the Slave Power - "this goliath of all monopolies."

... [If] the Money Power was the "master symbol" for the Age of Jackson, the Slave Power was equally effective as a symbol for all the fears and hostilities harbored by northerners toward slavery and the South. Morris and countless Jacksonians who later joined the Republican party showed how easily one could jump from one master symbol to the next. The fight against the Bank ... represented for the Jacksonians "equality against privilege, liberty against domination, honest work against dead precedent."72

The transformation from Jacksonian equal protection to antislavery equal protection produced enormous strain in the political and legal systems. Many state constitutions and statutes continued to discriminate against free blacks in the $1800-1860$ period, ${ }^{73}$ and courts

67. See generally M. TUSHNET, The AMERICAN LAW OF SLAVERY 1810-1860 (1981).

68. See generally Conant, supra note 50.

69. J. POLE, supra note 59 , at 146.

70. See Balkin, Some Realism About Pluralism: Legal Realist Approaches to the First Amendment, 1990 DUKE L.J. (forthcoming).

71. E. FONER, supra note 9, at 90.

72. Id. at 90-91 (citations omitted).

73. See H. Graham, supra note 14 , at 162. 
often responded with disingenuousness or silence. For example, Chief Justice Lemuel Shaw of Massachusetts in Commonwealth v. Alger ${ }^{74}$ fully endorsed the distinction between "class legislation and legislation enacted for the purpose of benefiting the polity as a whole" (p. 176). As Professor Nelson writes:

At issue in Alger was whether the state could limit the length to which docks extended into Boston harbor in order to insure the free passage of vessels in shipping channels. The court held that "all real estate ... is subject to some restraint for the general good" and that the legislature had "power, by general law affecting all ... equally and alike, to make reasonable regulations, declaring the public right." . . L Laws that benefited and affected all equally were to be distinguished, in turn, from class legislation - laws that, in common nineteenth century jargon, took property or rights away from A merely for the purpose of giving the same property or rights to B. Such class legislation was, of course, arbitrary and unreasonable. [pp. 176-77; footnotes omitted]

Yet, writing two years earlier, Shaw had concluded that separate schools for black and white students did not violate that principle. ${ }^{75}$

The important point about this period, despite many setbacks in the courts, is that the abolitionists and radical Republicans of that era were drawing on an existing concept of equal protection when they argued for eradicating slavery and protecting the rights of AfricanAmericans. ${ }^{76}$ When the phrase "equal protection" worked its way into the platforms and candidates' speeches of the Liberty, Free Soil, and Republican parties in the 1840-1860 period, 77 they were not inventing a concept to deal with the exigency of slavery; rather, they were reexamining an older concept, reshaping it in the service of their cause.'

As the concept of equal protection or equality under the law evolved, analytic problems also surfaced in nonracial cases. As the nineteenth century progressed, legislative supremacy in the states declined. Scandals tarnished many legislatures, and, in the Jacksonian era, voters began to fear landlords, creditors, and the wealthy - those who were thought to be too powerful in legislative processes. Restrictions on legislative power became more frequent, and often took the form of bans on local or special legislation. ${ }^{78}$ The most frequent in-

74. 61 Mass. (7 Cush.) 53 (1851).

75. Roberts v. City of Boston, 59 Mass. (5 Cush.) 198, 206 (1849); see also Van Camp v. Board of Educ. of Logan, 9 Ohio St. 326 (1859). See generally H. GraHAM, supra note 14, at 172-85; L. LEVY, THE LAW OF THE COMmONWEALTH AND CHIEF Justice SHAW (1957); J. PoLE, supra note 59, at 146-47; Baltimore \& Williams, The State Constitutional Roots of the "Separate But Equal" Doctrine: Roberts v. City of Boston, 17 RuTGERS L.J. 537 (1986).

76. See generally H. GRAHAM, supra note 14; Maltz, Fourteenth Amendment Concepts in the Antebellum Era, 32 AMER. J. LEGAL Hist. 305 (1988).

77. See H. GraHAM, supra note 14, at 301.

78. See L. FriedMAN, A History OF AMERICAN LAW, 107-08, 305 (1973); Benedict, supra note 45 . 
stances of unconstitutional special laws were those suspending a statute of limitations, granting rights of appeal, and authorizing divorces in particular instances when such rights were not generally available. ${ }^{79}$ Yet how were these laws different from special provisions for common carriers and bankers, and statutes granting corporate franchises to named persons, all of which were widely upheld? ${ }^{80}$

The conceptual disunity of equal protection in the antebellum period demonstrates a profound point about the idea of equality. Equality has no meaning without some prior conception of substantive rights, for we must determine how people are alike before we can apply equal protection standards. ${ }^{81}$ Yet the determination of likeness veils a substantive determination of rights, since equality will flow inextricably from such prior and "anterior constitutional standards." 82 If persons are to be treated with equal respect, then one must ascertain first those traits that entitle one to equal respect - and those traits will stem from a substantive concept of rights. ${ }^{83}$

There is no easy way out of this quandary. The equal protection clause in conjunction with the privileges and immunities clause of the fourteenth amendment is a substantive provision designed to secure liberty for all, not just racial minorities or other special groups. ${ }^{84}$ This objective was to be achieved through the concept of equality under law, connecting the antebellum insistence on general and abstract laws with the post-Civil War federal guarantee of equal protection. But the historical antipathy to class legislation and the distaste for special laws did not reflect a more general hostility toward classifications in law, for distinctions among groups for purposes of taxation, expending

79. T. CoOLey, supro note 22 , at $458-59$. Some lawyers even argued that all "judge-made law is special legislation" because of its ad hoc nature, and that "[a]ll American law must be a statute law." R. Rantoul, Oration at the Scituate (July 4, 1836), reprinted in THE LEGAL MIND IN AMERICA 222-27 (P. Miller ed. 1962).

80. T. Cooley, supra note 22 , at $457,460-62$; see also State v. Duffy, 7 Nev. 342,353 (1872) (concurring opinion); H. TAYLOR, supra note 41, at 829 . The rationality standard for reviewing such classifications is not very helpful. See Linde, Due Process of Lawmaking, 55 NEB. L. REv. 197 (1976). Hayek is exactly right when he says that to argue "that the law must not make irrelevant distinctions or that it must discriminate between persons for reasons which have no connection with the purpose of the law is little more than evading the issue." F. HAYEK, supra note 32, at 209 (footnote omitted); see also Bennett, "Mere" Rationality in Constitutional Law: Judicial Review and Democratic Theory, 67 CALIF. L. REv. 1049 (1979); Sunstein, Public Values, Private Interests, and the Equal Protection Clause, 1982 SUP. CT. REV. 127.

81. See, e.g., Sandalow, Racial Preferences in Higher Education: Political Responsibility and the Judicial Role, 42 U. CHI. L. REv. 653, 654-63 (1975); Sunstein, supra note 80, at 129-30; Westen, The Empty Idea of Equality, 95 HARv. L. REv. 537 (1982).

82. Westen, supra note 81, at 560; see also J. LuCAS, The PRINCIPLes OF Politics 250-51 (1966).

83. Westen, supra note 81 , at 549. See generally R. DWORKIN, TAKING RighTS SERIOUSLY 273 (1977).

84. See J. TENBROEK, supra note 8 , at 237; see also Conant, supra note 50, at 818-23, 829-30; Maltz, supra note 76 , at 323 . 
public funds, and police regulation were routine (p. 138). As Professor Nelson articulates the dilemma:

The very essence of all law is to discriminate - to separate out the occasions on which one legal consequence rather than an opposite one will obtain. A theory that the state should treat all people equally cannot mean that the state may never treat two people differently, for such a theory would mean the end of all law. In order to sustain a principle of equality under law - the principle for which the framers of the Fourteenth Amendment were striving, it is necessary to have some theory about when discrimination is appropriate and when it is not. [p. 138]

But what is the theory? The antebellum history of equal protections provides some elements of a general theory, some weak and strong forces that need to be taken into account, but no unified theory of equality. Classifications that express a raw preference for some individuals or classes over others, involving little concern for the general public good, are disfavored. The law should not favor the rich over the poor. Further, closed classifications and those involving immutable characteristics are greater restrictions on liberty than open classifications. If a special law allows only John Jones a discharge in bankruptcy or a divorce in particular circumstances, the law not only creates a class consisting of one person but also a closed class, to which no other person can fit himself or herself. As a prima facie matter, the law appears to be more concerned with favoring one citizen over others than it is with advancing the general good. The same problem occurs if a law is enacted to favor or disfavor people with red hair (p. 180). By contrast, if a tax is levied on real but not personal property, an individual may choose, perhaps with great difficulty, which form of property to hold. Open classifications of this type allow individuals to exercise their liberty more fully, giving them more control of the legal consequences of their decisions.

In addition, the role of tradition and cultural norms is difficult to deny. In examining the decisions of the Supreme Court in the late nineteenth century, Professor Nelson notes that the Court's decisions on the legitimacy of particular classifications often reflected prevailing attitudes among Americans:

The Court was able ... to avoid divisive declarations of principle and focus instead on questions of a more empirical nature about whether groups classified differently by legislation were, in fact, similar and hence entitled to equal treatment. At times, the Court was also able to take advantage of widespread agreement on specific factual assumptions about whether differences between people would justify legislation treating them differently. Thus in Bradwell it could rest on the widely shared perception that women should have a different social role than men, while in Bartemeyer it could rely on the shared understanding that prohibition laws were not enacted so that the class of nondrinkers would improve their welfare at the expense of drinkers, but in order to enhance the well-being of all. [p. 178] 
The incoherence of theory, of course, arises precisely because the intellectual underpinnings of equal protection could so easily come into conflict or be construed in different ways. To make the most obvious points, classifications involving racial and ethnic minorities and women may be traditional or largely affirmed in popular culture, and yet such classifications may be closed and evidence a crude preference for some classes of people over others. Most user fees imposed by government favor the affluent over the poor, and yet such fees are widely upheld. Some closed classifications, for example the selection of persons of a particular minimum age for military service, do not appear to reflect a class bias and may be defended on general welfare grounds.

From this perspective, and whatever the ambiguities, the constitutional affirmation of equality under the law and the resistance to retroactive laws and bills of attainder speak more generally to a larger principle of enhancing liberty. Every law or tax bespeaks a denial of liberty, as Jeremy Bentham once noted, but laws designed only to disfavor particular groups or to create closed classes are perhaps the most egregious denials of liberty, for they deny mature persons responsibility for their actions. ${ }^{85}$ The principle might be described as one of equal liberty or freedom. In this sense, state court decisions striking down special legislation and the evolution of fourteenth amendment protections for African-Americans and other groups both speak to the same underlying evils.

This approach to equal protection does not dispose of many of the most vexing dilemmas created by the concept. Whether a classification is based on legitimate dissimilarities - for example, whether and when children are incapable of making decisions for themselves - will spark disagreement, and cultural norms may well prevail. Children often are not governed by general laws, and their liberties often do not stand on the same footing as those of adults. Nor will there be consensus concerning which exigencies justify liberty-diminishing distinctions. The abstract principles embraced by the framers of the fourteenth amendment do not easily settle concrete disputes.

But one should not underestimate the impact of the historical roots of equality under law on modern equal protection theory. ${ }^{86}$ For example, the majority opinion in Morey v. Doud ${ }^{87}$ - a case that, unfortu-

85. See Sunstein, supra note 80 , at 131: "In brief, the Court requires differential treatment to be justified by reference to some public value. A justification that rests on the intrinsic value of treating one person differently from another is prohibited." See also B. ACKERMAN, SocIaL JUSTICE IN THE LIBERAL STATE (1980); Bennett, supra note 80.

86. See, e.g., Bennett supra note 80; Sunstein, supra note 80.

87. 354 U.S. 457 (1957). Compare Morey (Illinois statute prohibiting currency exchanges from doing business on the premises of another business, but specifically exempting the American Express Co. from the prohibition, denies competitors equal protection under the 14th Amendment.) with Pacific States Box \& Basket Co. v. White, 296 U.S. 176, 184 (1935) (Although 
nately, the Supreme Court later overruled as it rushed to abandon judicial review in the economic sphere ${ }^{88}$ - relies on the closed nature of a classification to invalidate a law under the equal protection clause; this analysis of closed classifications finds parallels in discussions of immutable biological differences, when the Justices determine whether a group constitutes a "suspect" class. ${ }^{89}$ But one also should not underestimate the differences between a liberty-based or equality-underlaw theory of equal protection and other glosses that have been placed on that provision.

Professor John Hart Ely, in an analysis that extrapolates from the historical plight of African-Americans to political structure, urges that the equal protection clause should be seen as protecting the openness of political processes. ${ }^{90}$ Equal protection is to be afforded to "discrete and insular" minorities, to use the famous phrase, ${ }^{91}$ and it should seek to open the pluralistic processes of governance in a democracy to those who have been politically isolated. Clearly, this approach draws on the racial origins of the equal protection clause, and it has much to commend it. But the Ely approach fails as a unitary theory of equal protection, for it overlooks the other intellectual currents underlying equality under law (p. 200). Professor Douglas Laycock aptly identifies the problem, for there is no historical basis for limiting the equal protection clause to such discrete and insular minorities, ${ }^{22}$ thereby elevating one vision of equal protection over all others. Equal protection may have its most immediate and important application to racial minorities and those who share similar characteristics, but it is not limited to such groups:

On any given issue, anybody can be discriminated against by a majority running roughshod over his interests, no matter how powerful he is more generally. The Constitution's recognition of this argues strongly against Ely's view that whites are largely left out of the equal protection clause because they do not need the protection.

... [Ely attempts] an impossible distinction between cases in which a group that is fairly represented in the political process loses on a particular issue or series of issues and cases in which a group is permanently excluded from effective political participation by the refusal of other groups to deal with it. ${ }^{93}$

the contested legislation did not operate to grant a monopoly, still, such a grant, if otherwise an appropriate exercise of the state's police power, is not void as denying equal protection.).

88. New Orleans v. Dukes, 427 U.S. 297 (1976). See generally Conant, supra note 50, at 738.

89. See, e.g., Plyler v. Doe, 457 U.S. 202, 216-17 n.14 (1981).

90. J. ELY, supra note 31.

91. United States v. Carolene Prod. Co., 304 U.S. 144, $152-53$ n.4 (1938). See generally Lusky, Footnote Redux: A Carolene Products Reminiscence, 82 Colum. L. Rev. 1093 (1982).

92. Laycock, supra note 39 , at 378.

93. Id. at 380-81 (citation omitted); see also Baker, Neutrality, Process, and Rationality: Flawed Interpretations of Equal Protection, 58 TEXAS L. REV. 1029 (1980). 
Equally important, Professor Ely ignores the fact that equal protection is for individuals, ${ }^{94}$ with group membership being important largely because government should not penalize an individual for ascribed characteristics that he or she shares with others. The equal protection clause makes no mention of groups; it says that "any person" is entitled to equal protection. ${ }^{95}$ An individual's rights should not turn only on whether there is an entire class of powerless victims. ${ }^{96}$ Finally, in the Ely vision, a modern functional approach to politics, informed by the first amendment and the republican form of government clause, substitutes itself for the vision of personal liberty and autonomy held by many nineteenth-century advocates of equal protection. .7

The historical vision of equal protection, focusing on class legislation and the equal provision of liberties, is reflected more strongly, however, in the "public value" approach advocated in recent years by Professor Cass Sunstein and Dean Robert Bennett.98 The equal protection clause, from their perspective, forbids "unprincipled" discriminations that are premised on the view that "it is intrinsically desirable to treat one person better than another." 99 It rejects the notion of "rationality" review; for rational relationship tests for assessing the fit between means and ends are meaningless unless the equal protection clause limits "the universe of permissible statutory purposes."100 Indeed, most laws may not be analytically rational, but may simply reflect a legitimate political bargaining process - the law passed was the best one possible given conflicting values and goals and the need to achieve a majority. ${ }^{101}$ It requires, however, that laws must be general. "When the government operates to benefit A and burden B, it may do so only if it is prepared to justify its decision by reference to a public value. $A$ bare decision to prefer $A$ to $B$, because the comparative disadvantage is intrinsically desirable, is not sufficient."102

The public value approach is reflected, albeit somewhat erratically,

94. As Professor Laycock states,

Only by assessing the political power of a group can [Ely] determine whether legislation affecting that group adversely is suspect. His view that women may waive their right to equal treatment by not pressing hard enough for it politically also highlights his focus on groups as the unit of analysis.

Laycock, supra note 39, at 378 (footnote omitted).

95. Id. at 378.

96. Id. at 378-79.

97. Id. at 383.

98. See Bennett, supra note 80; Sunstein, supra note 80; see also Bice, Rationality Analysis in Constitutional Law, 65 MiNN. L. Rev. 1 (1980).

99. Sunstein, supra note 80 , at 128.

100. Id. at 130.

101. See Linde, supra note 80; Yudof, Plato's Ideal and the Perversity of Politics (Book Review), 81 MrCH. L. REV. 730 (1983).

102. Sunstein, supra note 80 , at 134 . 
in constitutional history. According to Professor Nelson, James Bradley Thayer, the famous constitutional law scholar, told his students that the "first question [in equal protection analysis] is whether there is a rational public reason for [the classification]. A class cannot be selected because they have red hair, but ... [only] on the ground of some rational public reason" (p. 180; citation omitted). Justice Stephen Field also sought to distinguish between class legislation and run-of-the-mill legislative classifications. Consider this passage from Field's decision for the Court in Barbier v. Connolly: 103

Special burdens are often necessary for general benefits - for supplying water, preventing fires, lighting districts, cleaning streets, opening parks, and many other objects. Regulations for these purposes may press with more or less weight upon one than upon another, but they are designed, not to impose unequal or unnecessary restrictions upon any one, but to promote ... the general good. Though, in many respects, necessarily special in their character, they do not furnish just ground of complaint if they operate alike upon all persons and property under the same circumstances and conditions. Class legislation, discriminating against some and favoring others, is prohibited, but legislation which, in carrying out a public purpose, is limited in its application ... is not within the [fourteenth] amendment. 104

Concurring with Bennett and Sunstein, Professor Richard Kay argues that the vision of equal protection embodied in such decisions is that a "mere preference of one group over another, that is, legislation based only on favoritism or on spite, is outside the scope of proper governmental activity." 105

Note three things about the "public value" approach to equal protection. First, race is simply one example of an unjustifiable classification. ${ }^{106}$ A law may involve unconstitutional class legislation even though there is little analogy to the plight of African-Americans. As Senator Jacob Howard, a floor leader for the fourteenth amendment, said about the equal protection clause, "it abolishes all class legislation in the States and does away with the injustice of subjecting one caste of persons to a code not applicable to another." 107 Second, public values or legitimate governmental objectives are defined so as to exclude class or racial bias. This is fully consistent with Professor Nelson's history of the fourteenth amendment. Third, the line between class prejudice and reasonable regulation is so difficult to draw - often either explanation may be plausible for a particular law - that there is enormous temptation to adopt a motivation test. What was the purpose of the law? Was it enacted only to favor or disfavor a particular class of

103. 113 U.S. 27 (1885).

104. 113 U.S. at 31-32.

105. Kay, supra note 15, at 696.

106. $I d$.

107. Frank \& Munro, supra note 40 , at 441. 
citizens, or was there some overarching public welfare purpose? Are the injuries imposed on the losers simply incidental to accomplishing another proper purpose or was the infliction of the loss the primary goal in the first place?

One advantage to the "public value" standard is that it does not turn on only a functional view of politics, with the overlay of modern theories of pluralism; rather, it focuses on the nature of the classifications and admits of the application of equal protection to all persons - not just powerless minorities. ${ }^{108}$ But, as Professor Sunstein admits, the inquiry into motivation is treacherous, requiring a rather refined and sophisticated inquiry into legislative purposes. ${ }^{109}$ Succinctly, legislatures may not reveal their real reasons for creating a classification, or there may be no consensus among legislators on the purpose of a measure. ${ }^{110}$ Equally important, however, legislatures generally believe that their enactments further public values. They may believe that racially segregated neighborhoods and schools will promote racial harmony, or that laws discriminating against women workers promote the well-being of families. If there is something wrong with these classifications, one must either have a restricted definition of "public values" or hold the view that some classifications, even in furtherance of legitimate public values, are impermissible.

\section{IV}

In this Part, I explore the idea that the historical concept of equal protection, rooted in the nineteenth-century commitment to equality under law and animus to class legislation, is fully applicable to discrimination on the basis of sex. ${ }^{111}$ The issue should be framed with some care. If history in the sense of the specific intentions of the framers of the fourteenth amendment is treated as decisive, my assertion is most assuredly incorrect. ${ }^{112}$ Classification by sex was widely accepted as legitimate in the nineteenth century, presumably being based on widespread sentiments (at least among men) that such laws were reasonable and did not involve class legislation.

There is little evidence in the debates over the fourteenth amendment of a specific concern with sex discrimination. Professor Nelson devotes a number of pages to the question, but the historical record is sparse. (pp. 136-38, 152, 165-66) Leading feminists opposed adoption of the fourteenth amendment because it inserted the word "male" into

108. Sunstein, supra note 80 , at 131-35.

109. Id. at 131.

110. See generally Brest, The Misconceived Quest for the Original Understanding, 60 B.U. L. REV. 204 (1980).

111. The argument made here is drawn from D. KIRP, M. YUdoF \& M. FRANKS, GENDER JUSTICE 116-20 (1986).

112. See generally J. PoLE, supra note 59 , at 174-76. 
the Constitution for the first time, implying that state governments could deny women the vote; 113 they unsuccessfully sought to add sex to the list of impermissible bases for denying suffrage under the fifteenth amendment. ${ }^{114}$ Their position, however, found some sporadic support. For example, Republican Senator John B. Henderson "was one of a very few who found it difficult to understand why, under section two of the [fourteenth] amendment, states should be deprived of representation if blacks were not allowed to vote but would suffer no similar penalty if women were denied the franchise" (p. 137). He opined that the "distinction was a mere matter of temporary expediency" and that "[i]f there be no principle involved, then the amendment should not be made" (pp. 137-38; citation omitted).

Republican proponents of the fourteenth amendment, who were opposed to including women within the ambit of equal protection, responded in a variety of ways. Some urged that women were not the equals of men (p. 138). Thaddeus Stevens, invoking a common prestidigitation with the concept of equality, simply said that " " $[w]$ hen a distinction is made between two married people or two femmes sole, then it is unequal legislation; but where all of the same class are dealt with in the same way then there is no pretense of inequality" " (p. 139; citation omitted). Others argued that women were adequately represented by their male fathers, husbands, and friends (p. 138). Charles Sumner simply opined that it was not the right political moment for women:

[He] wanted to leave the question "whether women shall be invested with the elective franchise... untouched, contenting myself with saying, that it is obviously the great question of the future, which will be easily settled, whenever the women in any considerable proportion insist that it shall be settled." For nearly all Republicans, "the enfranchisement of women and the enfranchisement of the blacks" had to remain separate and distinct since 1866 was " 'the negro's hour....." [p. 137]

The issue of sex discrimination often entered into the discussions of the framers of the fourteenth amendment in ways analogous to the consideration of sex in the passage of Title VII of the Civil Rights Act of 1964, almost a hundred years later: opponents and not proponents of the amendment argued for the broader interpretation. Conservatives urged that equality under law, as embodied in the post-Civil War amendments, is a unitary concept, that "if you wrong the African ... you wrong the woman. She has the same natural right to vote that the African has."11s Senator Edgar Cowan, in the debate over the Civil

113. Section 2 of the amendment reads in part: "But when the right to vote . . . is denied to any of the male inhabitants ..., the basis of representation therein shall be reduced ...." U.S. CoNST. amend. XIV, $\$ 2$ (emphasis added).

114. B. Babcock, A. FreEdman, E. Norton \& S. Ross, Sex Discrimination and the LAW 4 (1975).

115. J. Pole, supra note 59, at 175 (quoting James Dixon). 
Rights Act of 1866, was even more emphatic:

[The Act confers] ... upon married women, upon minors, upon idiots, upon lunatics, and upon everybody native born in all the States, the right to make and enforce contracts, because there is no qualification in the bill, and the very object of the bill is to override the qualifications that are upon those rights in the States. [p. 107; footnote omitted]

By expansively interpreting equality notions to include women and others, opponents of equal protection hoped to ridicule the fourteenth amendment and to show its unwisdom. ${ }^{116}$ Most radical Republicans did not rise to the bait, but a few did proceed "from the principle of equality as applied to individuals regardless of property or race to equality regardless of sex."117 The impression is that many radicals well understood the implications of their principles for women, but, largely for fear of providing ammunition to opponents of the fourteenth amendment, they chose not to address specifically the question of sex discrimination by the states. ${ }^{118}$

If one agrees with Leonard Levy, however, that "[t]he principles and not their framers' understanding and application of them are meant to endure," 119 then there is a strong case for treating sex classifications as illegitimate under the equal protection clause. To demonstrate this point, I turn to a much vilified source of constitutional principles, Herbert Spencer's Social Statics; or, The Conditions Essential to Human Happiness, first published in 1851. Spencer was a British contemporary of the framers of the fourteenth amendment, and he drew upon many of the same intellectual traditions of liberal philosophy and social Darwinism that they did.

To focus on the work of Herbert Spencer is to invite the contempt of generations of constitutionalists, for Spencer is identified with the worst excesses of substantive due process between the adoption of the fourteenth amendment and the ascension of the New Deal Court in the late 1930s. In the most infamous substantive due process case in constitutional history, Lochner v. New York, ${ }^{120}$ Justice Holmes ensured that every law student would come to know the evil wrought by Mr. Spencer. In that case, Holmes vehemently dissented from the majority's decision to declare unconstitutional a New York law limiting the hours of employment of bakery employees. Holmes was incensed by what he believed was the substitution of the majority's own political and economic philosophy for that of the legislature in the guise of

116. Id. at 174-75.

117. Id. at 175.

118. Id. at 175-76.

119. L. Levy, Legacy of Suppression: Freedom of Speech and Press in Early AMERICAN HISTORY 309 (1960).

120. 198 U.S. 45 (1905). See generally W. SWINDLER, COURT AND CONSTITUTION IN THE Twentieth Century: The Old Legality, 1889-1932 (1969); Benedict, supra note 45. 
constitutional law. And, in perhaps the most famous put-down in American judicial history, he chastised his fellow justices for reading Herbert Spencer's brand of utilitarian philosophy into the Constitution:

This case is decided upon an economic theory which a large part of the country does not entertain. If it were a question whether I agreed with that theory, I should desire to study it further and long before making up my mind. But I do not conceive that to be my duty, because I strongly believe that my agreement or disagreement has nothing to do with the right of a majority to embody their opinions in law. It is settled by various decisions of this court that ... state laws may regulate life in many ways which we as legislators might think as injudicious or if you like as tyrannical as this .... The liberty of the citizen to do as he likes so long as he does not interfere with the liberty of others to do the same, which has been a shibboleth for some well-known writers, is interfered with by school laws, by the Post Office, by every state or municipal institution which takes his money for purposes thought desirable, whether he likes it or not. The 14th Amendment does not enact Mr. Herbert Spencer's Social Statics. ${ }^{121}$

Justice Holmes quite obviously was familiar with Herbert Spencer's Social Statics, ${ }^{122}$ and, despite the disclaimer that he had not made up his mind on Spencer's theory, he clearly was not thrilled by the insights of an unreconstructed nineteenth-century liberal - at least where they were to be imposed by courts. ${ }^{123}$ Spencer opposed government administration of schools as an unnecessary and totalitarian impulse, ${ }^{124}$ he thought that government delivery of the mail was based on the infringement of the liberty of those who were forbidden from competing, ${ }^{125}$ and he viewed virtually all taxes as an assault on liberty, ${ }^{126}$ including taxes to support public health and sanitation measures. ${ }^{127}$ $\mathrm{He}$ also felt that state interference with the liberty to exchange one's property or labor was one of "the worst violations of human rights."128

But in areas not dealing with regulation of commerce, taxation, and public services, Spencer expressed views that Justice Holmes might have found more compatible with his constitutional principles. Spencer, ever the rigorous devotee of liberal philosophy, methodically

121. 198 U.S. at 75 (emphasis added).

122. H. SPENCER, supra note 1. The views of Justice Holmes on Spencer and Social Darwinism are complex, and the reader should consult the excellent work of Professor Hovenkamp. See Hovenkamp, Evolutionary Models in Jurisprudence, 64 TEXAS L. REv. 645, 660-64 (1985).

123. Hovenkamp, supra note 122 , at $660-61$.

124. H. SPENCER, supra note 1 , at 360-65.

125. Id. at 440 .

126. Id. at 307.

127. Id. at 407.

128. Id. at 329. 
and rigidly applied that philosophy to all manner of legal and policy questions, allowing it to lead him where it may. For example, he argued that "nothing is to be feared from the most uncontrolled utterances of thought and feeling," 129 a position on freedom of expression more akin to, though perhaps more absolutist than, that of Justice Holmes. In the present context, however, I wish to explore Spencer's conception of equality under law, a conception that bears marked similarities to the Framers' own contemporaneous vision.

Spencer's basic thesis in Social Statics is that "man's happiness can only be produced by the exercise of his faculties" and that to exercise those faculties "he must have liberty to do all that his faculties naturally impel him to do."130 Man thus "has a right to that liberty," and such a right fulfills the Divine will.131 The problem is that liberties may conflict, and thus there arises the need for limits on liberty. ${ }^{132} \mathrm{He}$ then embraces the Millian proposition"133 "that every man may claim the fullest liberty to exercise his faculties compatible with the possession of like liberty by every other man."134 But in the practical world of human affairs "detailed knowledge" of the "human constitution" and the consequences of human action are "unattainable," and hence the only practical solution is that "the law of equal freedom" should be recognized as the only "limit to the exercise of the faculties."135 The argument becomes murkier at this point, but it apparently is along the lines that equal constraints on liberty, inflicting benefit or harm on everyone, will lead to the abandonment of limitations on liberty that are not required to avoid inflicting injury on others. ${ }^{136}$ Thus, he concludes:

Freedom being the prerequisite to normal life in the individual, equal freedom becomes the prerequisite to normal life in society. And if this law of equal freedom is the primary law of right relationship between man and man, then no desire to get fulfilled a secondary law can warrant us in breaking it. ${ }^{137}$

Spencer's basic proposition of "equal freedom" bears a great similarity to the antebellum notions of equality under law and the need for general laws that do not favor a particular class. And, like his contemporaries in America, he also is better at articulating the general theory than in working through all of its applications. He is remarkably si-

129. Id. at 171 .

130. Id. at 93.

131. Id.

132. $I d$.

133. See J. MiLl, ON LiberTy (1859).

134. H. SPENCER, supra note 1 , at $93-94$.

135. Id. at 102 .

136. $I d$.

137. Id. at 106. William Graham Sumner, an American Social Darwinist, took a similar view of the meaning of equality. See Hovenkamp, supra note 122, at 669. 
lent on the question of how one distinguishes between a violation of equal freedom and the advancement of legitimate state objectives through laws that classify people. Perhaps this is less of a problem for him because he sees such a limited role for government. But what is intriguing about Spencer's concept of equal freedom is that he saw it as fully applicable to women and protective of their liberties:

Equity knows no difference of sex. In its vocabulary the word man must be understood in a generic, and not in a specific sense. The law of equal freedom manifestly applies to the whole race - female as well as male. The same a priori reasoning which establishes that law for men ... may be used with equal cogency on behalf of women. The Moral Sense, by virtue of which the masculine mind responds to that law, exists in the feminine mind as well. Hence the several rights deducible from that law must appertain equally to both sexes. ${ }^{138}$

Spencer devotes an entire chapter of Social Statics to "The Rights of Women" 139 and he is at great pains to establish that the principle of equal freedom does not permit discrimination based on sex. He denies that "the differences of bodily organization, and those trifling mental variations which distinguish female from male, should exclude onehalf of the race from the benefits" of equal freedom. ${ }^{140}$ The burden of proof lies with those who would deny that women are the equals of men and assert that they are "creatures of an inferior order," 141 and he concludes that no such showing can be made. ${ }^{142} \mathrm{He}$ also suggests that even if he is wrong on his facts, the argument for nondiscrimination against women is compelling:

Not only, however, does the theory ... fall to pieces under the mere process of inspection; it is absurd on the very face of it .... For what is it that we mean by rights? Nothing else than freedom to exercise the faculties. And what is the meaning of the assertion that woman is mentally inferior to man? Simply that her faculties are less powerful. What then does the dogma, that because woman is mentally inferior to man she has less extensive rights, amount to? Just this - that because woman has weaker faculties than man, she ought to have like liberty with him, to exercise the faculties she has/ ${ }^{143}$

Spencer's conclusion, which might easily have been reached by a modern court, is that judgments about the relative capacities of women are likely to be based on stereotypes and not facts and that, in any event, the principle of equal freedom would allow women to exercise whatever faculties they possess. There simply is no need to reinforce the stereotypes through law, whatever one's view of their correctness.

138. H. SPENCER, supra note 1, at 173.

139. Id. at 173-91.

140. Id. at 173 .

141. Id. at 173-74.

142. Id. at 175.

143. Id. at 177 . 
His conclusion is that the unequal treatment of women and blacks is more a function of the selfishness of the dominant groups than it is a function of the logical application of the principle of equal freedom. ${ }^{144}$ Indeed, he confides that once the arguments for the unequal treatment of women are no longer left to tacit understanding ${ }^{145}$ but are brought into the open, "Few will have [the] hardihood to assert" their inferiority. 146

Spencer's conclusion that women were entitled to equality under the law does not necessarily mean that his vision was embraced in the concept of equal protection in the fourteenth amendment. Justice Holmes' admonition is still well recalled. But there were signs, however inchoate, that American law was moving in that direction even prior to the adoption of the amendment. In the first half of the nineteenth century, women had benefited enormously from the movement away from status and toward individual liberty, even if that movement was more a reflection of economic changes than of changing perceptions of the place of women. ${ }^{147}$ In 1839 , Mississippi recognized the legal capacity of women, and by 1850 about half of the states had enacted laws recognizing the property rights of married women. ${ }^{148}$ These new laws were not extensively debated in legislative bodies, and they did not receive significant attention in the press. ${ }^{149}$ Litigation arising out of the Married Women's Property Acts was largely initiated by creditors, with very few cases litigated between husbands and wives. Lawrence Friedman describes these laws as the ratification of a "silent revolution."'150

Friedman's description gives us a clue to the profound difficulties of discussing sex classifications and the scheme of the fourteenth amendment. Sex classifications disadvantaging women were largely viewed as paternalistic and benign. ${ }^{151}$ Where such paternalism appeared ill-suited and inconsistent with economic necessity, significant changes were made in state laws. Thus, sex discrimination simply was not viewed as a problem by many, and state bans on special legislation and provisions on equality under law generally were not invoked to strike down such discrimination. This inability to recognize sex classifications as inconsistent with equality under law carried over into the debates over the fourteenth amendment.

144. Id. at 178-79.

145. Id. at 173 .

146. Id. at 174 .

147. L. Friedman, supra note 78 , at 186.

148. H. HYMAN \& W. WIECEK, supra note 11, at 51. See generally Chused, Married Women's Property Law: 1800-1850, 71 GEO. L.J. 1359 (1983).

149. L. FRIEDMAN, supra note 78 , at 186.

150. Id.

151. See D. KIRP, M. YUdof \& M. FranKs, supra note 111 , at 119. 
But status came to take on a larger meaning after the Civil War, referring to the assignment of legal rights and obligations on the basis of ascribed and not achieved characteristics. ${ }^{152}$ It is interesting to note in this regard that the Civil War amendments to the Constitution make reference to two types of status distinctions. The thirteenth amendment, abolishing slavery, naturally refers to slavery and involuntary servitude. ${ }^{153}$ The fourteenth amendment makes no reference to slavery at all. But the fifteenth amendment states that the rights of citizen of the United States to vote shall not be abridged "on account of race, color, or previous condition of servitude."154 Arbitrariness lies in classifying persons in accordance with their birthrights (slave status) or other characteristics (race) over which they have little or no control; a reasonable classification takes into account their wills, the things they are able to choose to do or not do within the limits of their capacities and the social order. ${ }^{155}$

Until the twentieth century, litigants attacking the constitutionality of unequal treatment of women under the law relied almost exclusively on the privileges and immunities clause of the fourteenth amendment, not equal protection. ${ }^{156}$ In the Slaughter-House Cases, ${ }^{157}$ the Supreme Court effectively read the privileges and immunities clause out of the fourteenth amendment; one day later, in Bradwell v. State, ${ }^{158}$ the Court held that denying Myra Bradwell a license to practice law on the basis of her sex did not violate the privileges and immunities clause. ${ }^{159}$ The following Term, in Minor v. Happersett, 160 the Court unanimously rejected a woman's insistence that a state statute rendering her ineligible to vote in national elections violated the privileges and immunities clause.

Perhaps it is worth pausing to consider the Slaughter-House and Minor cases. Distinguished historians such as Charles Fairman have found it intriguing that the first Supreme Court case to construe directly the privileges and immunities, due process, and equal protection clauses of the fourteenth amendment involved Southern whites, who wished to challenge "carpetbagger" legislation, and not black victims

152. See F. HaYeK, supra note 32, at 154. See generally P. AtiYAH, The Rise AND Fall OF FREEDOM OF CONTRACT (1979).

153. U.S. ConsT. amend. XIII, $\S 1$.

154. U.S. CoNST. amend. XV, $\S 1$.

155. See F. HAYEK, supra note 32, at 170.

156. See R. LeE, A LAWYer Looks at the Equal Rights AmENDMent (1981).

157. 83 U.S. (16 Wall.) 36 (1873).

158. 83 U.S. (16 Wall.) 130 (1873).

159. Compare Bradwell, 83 U.S. (16 Wall) 130 (1872) with In re Leach, 134 Ind. 665,34 N.E. 641 (1893) (Neither the Indiana Constitution nor its laws deny women the right to practice law in the state, and upon application, and proper evidence, they are entitled to admission to the bar.).

160. 88 U.S. (21 Wall.) 162 (1874). 
of discrimination. 161 More than a thousand butchers were put out of work by the legislation, and their contention was that the establishment of the slaughter-house monopoly, largely through bribery in the Louisiana legislature, deprived them of the liberty to pursue a lawful employment. ${ }^{162}$ The plaintiffs' briefs drew on old English law concerning monopolies, and on an array of learning and natural law to establish that liberty to pursue one's chosen employment was a protected constitutional privilege. ${ }^{163}$ The standard explanation for this extraordinary appeal by white southerners to a constitutional amendment addressed to protecting blacks is that the plaintiffs had no choice since Louisiana courts were dominated by unsympathetic carpetbaggers. ${ }^{164}$ In addition, the butchers hired former Supreme Court Justice John A. Campbell to represent them, and it was thought that he might "captivate the minds of the Justices."165

The Court's resolution of the case has been attacked from many quarters. ${ }^{166}$ A five-Justice majority held that plaintiffs had not been denied any protected privileges and immunities, and, in a few tortuously reasoned passages, forever sapped that clause of any significant meaning. 167 Justice Miller also expressed his "doubt . . . whether any action of a State not directed by way of discrimination against the negroes as a class, or on account of their race, will ever be held to come within the purview of [the fourteenth amendment]."168

But whatever the Court's treatment of the natural law and equality-under-law components of the amendment, many applauded the majority's unwillingness to embrace a laissez-faire philosophy in the garb of constitutional doctrine. ${ }^{169}$ For a brief time at least, the Justices were not swayed by Mr. Herbert Spencer's utilitarian philosophy. Conversely, the dissenters took a broader view of privileges and immunities, but appeared to lay the groundwork for now-repudiated notions of substantive due process and the need to protect economic liberties

161. 6 C. FAIRMAN, History of THE Supreme COURT OF THE UNITEd States: RecoNSTRUCTION AND REUNION 1864-88: PART ONE 1308 (1971) (The Slaughter-House Case "was all out of accord with what members of Congress had had in mind in their debates.").

162. Id. at 1321-32; see also 2 C. WARREN, The Supreme Court in UNITEd STATEs HisTORY 533-61 (1932); Conant, supra note 50, at 823-28.

163. See 6 LANDMARK BRIEFS AND ARguments of THE SUPREME COURT OF THE UNITED States: Constitutional LAW 535-683 (P. Kurland \& G. Casper eds. 1975). See generally Conant, supra note 50.

164. See C. FAIRMAN, supra note 161, at 1319. But see Conant, supra note 50.

165. C. FAIRMAN, supra note 161, at 1319.

166. See, e.g., L. LUSKY, BY WHAT RIGHT? 194-98 (1975); Conant, supra note 50, at 825-26; Graham, Our "Declaratory" Fourteenth Amendment, 7 STAN. L. REv. 3 (1954).

167. Slaughter-House Cases, 83 U.S. (16 Wall.) 36 (1873); see also L. LuSKY, supra note 166, at $194-98$.

168. 83 U.S. (16 Wall.) at 81 ; see p. 162.

169. See, e.g., C. FAIRMAN, supra note 161, at 1370-74; H. GraHAM, supra note 14, at 113. 
from government regulation. ${ }^{170}$ These interpretations of the Slaughter-House Cases have much to commend them, as does the view that a conservative majority on the Court was seeking to restrain the very federal power that radical Republican Congresses had sought to expand. ${ }^{171}$ The result in this case may well have turned more on conceptions of federalism and of appropriate limits on federal courts than a careful parsing of the terms of the fourteenth amendment (pp. 162-63).

While, to be sure, the various opinions and briefs in the SlaughterHouse Cases are confused and conflicting, reflecting the complexity of the issues and the paucity of federal precedents, ${ }^{172}$ there is an alternative hypothesis that would explain the filing of such a suit (pp. 15860). The Louisiana statute named seventeen specific incorporators of the Crescent City Company who were to benefit from the monopolycreating law ${ }^{173}$ and the public health rationale for the statute may have been a blatant subterfuge for special legislation to benefit a known and identified small group of citizens. ${ }^{174}$ From this perspective, the claims of the plaintiffs flowed naturally from the conception of equal protection that preceded the adoption of the fourteenth amendment (p. 156). The class was closed, and the beneficiaries were specifically named and not identified by their superior capacity to carry out particular functions. The law was not general and abstract; it favored a particular set of individuals. One may concede that Louisiana may regulate slaughter-houses for the general welfare, compelling them to locate outside of New Orleans, without conceding that it has the power to pass such special legislation. ${ }^{175}$ Indeed, one reading of Justice Miller's majority opinion is that he agreed with this statement of principle but disagreed on its application to the facts of the case (pp. 158-60).

Unfortunately, Justice Miller also sought to support his decision against the butchers with arguments that the fourteenth amendment only protected African-Americans. He did so, however, in complete disregard of history. Professor Nelson is exactly right in pointing out the error of Miller's ways:

Justice Miller's approaches for narrowing the reach of section one were

170. C. FAIRMAN, supra note 161, at 1385. See Forbath, The Ambiguities of Free Labor: Labor and the Law in the Gilded Age, 1985 WIS. L. REv. 767; Conant, supra note 50, at 828 n.198. See generally Kay, supra note 15 .

171. C. FAIRMAN, supra note 161, at 1321. See also Murphy, Slaughter-House, Civil Rights, and Limits on Constitutional Change 32 AM. J. JURIS. 1 (1987).

172. For example, the plaintiff' attorney in his brief discussed the 1848 Republican Constitution of France, Macaulay, Fortescue, and numerous English cases on monopolies. See Kurland \& Casper, supra note 163 , at 550-62.

173. C. FAIRMAN, supra note 161 , at 1322.

174. Id. at 1322-23; see also Live-Stock Dealers' \& Butchers' Assn. v. Crescent City LiveStock Landing \& Slaughter-House Co., 15 F. Cas. 649, 653 (C.C.D. La. 1870) (Bradley, J.).

175. Professor Conant reaches the same conclusion through a historical reconstruction of the privileges and immunities clause. See Conant, supra note 50. 
flatly inconsistent with the history of its framing in Congress and its ratification by the state legislatures. ... While equality for blacks was surely the central concern of the amendment's framers and ratifiers, it was never their sole and exclusive concern. Those who discussed the amendment were aware of its implications for other groups, such as Chinese, Indians, women, and religious minorities. Moreover, there is no doubt that the proponents of the amendment meant to protect yet another group - namely, Northern whites who were migrating to the South after the Civil War and were threatened with potentially discriminatory legislation at the hands of Southern states and localities. It was simply wrong for Justice Miller to suggest that the Fourteenth Amendment could be limited only to cases of discrimination against blacks. [p. 163]

Thus, by unnecessarily going beyond the narrowest ground on which his decision might have rested, perhaps to reply to the assertions of the dissenters (p. 162), Justice Miller did incalculable damage to fourteenth amendment jurisprudence. In one opinion he managed to demolish the natural law and equality-under-law underpinnings that were so much in evidence only a few years earlier.

Justice Field, perceiving an equal protection component in the privileges and immunities clause, ${ }^{176}$ adhered to an equality-under-law approach when he opined that government might provide for exclusive franchises in extraordinary circumstances or regulate generally for the public convenience, but this is very different "from a grant, with exclusive privileges, of a right to pursue one of the ordinary trades or callings of life, which is a right appertaining solely to the individual." 177 It is one thing to proscribe regulations for all, even if it impedes employment choices, and quite another to name those citizens who may pursue a calling and those who may not: "The fourteenth amendment, in my judgment, makes it essential to the validity of the legislation of every State that this equality of right should be respected."178 Lest one accuse Field of too radical a bent, he defined equality of liberty in the following terms: "To [citizens of the United States] everywhere, all pursuits, all professions, all avocations are open without other restrictions than such as are imposed equally upon all others of the same age, sex, and condition." 179 Thus, with the addition of race to the list of impermissible classifications, Field saw equality-underlaw in very much the same terms as Jacksonians forty years earlier.

The contention that the Slaughter-House Cases raised issues within the core of the concerns of the framers of the fourteenth amendment is reinforced by reactions to the decision in Louisiana. ${ }^{180}$ For example,

176. Id. at $826-27$.

177. Slaughter-House Cases, 83 U.S. (16 Wall.) 36, 88 (1873) (Field, J., dissenting).

178. 83 U.S. (16 Wall.) at 110.

179. 83 U.S. (16 Wall.) at 110.

180. See C. FalRman, supra note 161 , at 1371-74, 1379-80. 
when Francies R.T. Nichols, the candidate for Governor of the Democratic Party in 1876, finally ousted the Republican regime, he declared "that he would "carry out faithfully and impartially the amendments to the Constitution' and that he was 'utterly opposed to class legislation." "181 In 1881, the city council of New Orleans abolished the monopoly pursuant to an 1879 state constitutional amendment. ${ }^{182}$ The company challenged the abolition as a violation of the contract clause, and in 1884 the Supreme Court unanimously sustained the law. ${ }^{183}$

In a concurring opinion in the second litigation, Justice Field covered much of the same ground as in his dissenting opinion in the first case, arguing that only age, sex, and condition might be taken into account in distinguishing among ascribed characteristics of persons. ${ }^{184}$ But he also sharpened his views. The fourteenth amendment did not "limit the subjects upon which the States can legislate":

They can now, as then, legislate to promote health, good order and peace, to develop their resources, enlarge their industries, and advance their prosperity. It only inhibits discriminating and partial enactments, favoring some to the impairment of the rights of others. The principal, if not the sole, purpose of its prohibitions is to prevent arbitrary invasion by State authority of the rights of person and property, and to secure to every one the right to pursue his happiness unrestrained, except by just, equal, and impartial laws. ${ }^{185}$

Justice Bradley's concurring opinion was equally emphatic. The states might constitutionally apply "general regulations, applying equally to all, as the general good may demand ...."186 But Louisiana's monopoly law violated "the last clause of the section - 'no State shall deny to any person the equal protection of the laws." "

If it is not a denial of the equal protection of the laws to grant to one man, or set of men, the privilege of following an ordinary calling in a large community, and to deny it to all others, it is difficult to understand what would come within the constitutional prohibition. ${ }^{187}$

In Bartemeyer v. Iowa, ${ }^{188}$ Justice Bradley had said much the same thing. The tragedy of later Court decisions is that they ignored the equal protection principles inherent in the earlier Field and Bradley positions and the concessions to state regulatory power, and chose to

181. Id. at 1379 .

182. Id. at 1380 .

183. Butchers' Union Co. v. Crescent City Co., 111 U.S. 746 (1884).

184. 111 U.S. at 757 (Field, J., concurring).

185. 111 U.S. at 759; see also American Sugar Ref. Co. v. Louisiana, 179 U.S. 89 (1900); Bell's Gap R.R. v. Pennsylvania, 134 U.S. 232 (1890); Barbier v. Connolly, 113 U.S. 27 (1885). See generally Kay, supra note 15.

186. 111 U.S. at 763 (Bradley, J., concurring).

187. 111 U.S. at 765-66 (Bradley, J., concurring).

188. 85 U.S. (18 Wall.) 129 (1873). 
amplify the looser language relating to the right to pursue a calling or business. As Professor Gordon has noted:

Men like Cooley, Dillon, Field and Miller, who helped put the structure together, were old Jacksonians and intensely suspicious of corporate privilege. Their desire to limit legislative power stemmed as much from terror of a corrupt legislative-corporate alliance as from the specter of radicalism; they wanted to eliminate all legal patronage of particularism. Besides, [the theory] did not condemn the exercise of state power as long as it remained within its proper sphere, and the extensive regulation of public service corporations, occupations, and morals in the late nineteenth century ... showed how broad the sphere could be. ${ }^{189}$

The Minor decision ${ }^{190}$ casts some light on the discomfiture of the nation's highest court with state-sanctioned sex discrimination, despite its tolerance of such inequalities under the law. The Minor Court went to considerable lengths to confirm the fact that women were citizens of the United States and persons under the Constitution. It noted that women were members of the polity, that the Constitution was established by "the people," including women, and that (in contrast to its discredited decision in the Dred Scott case on blacks) women had long been treated as citizens for purposes of federal diversity jurisdiction over controversies between citizens of different states. ${ }^{191}$ The Chief Justice even opined that "[t]here cannot be a nation without a people," and that women had always been citizens, the fourteenth amendment not having affected "the citizenship of women any more than it did of men."192

How then did Mrs. Minor lose her lawsuit? The Court extensively reviewed the franchise under state constitutions at the time of the adoption of the federal constitution, and found that the states disenfranchised many citizens, including women. Further, the privileges and immunities clause of article IV of the Constitution, giving the citizens of each state rights in their several states, ${ }^{193}$ had never been construed so as to give a citizen a right to vote in more than one state. In short, in the absence of express language to the contrary, the Court concluded that the right to vote was not among the privileges and immunities protected by the fourteenth amendment. ${ }^{194}$

This conclusion was bolstered by a logical point: "If suffrage was one of these privileges or immunities, why amend the Constitution to prevent its being denied on account of race, etc.?"195 This reference to

189. Gordon, supra note 56 , at $92-93$ (footnotes omitted).

190. Minor v. Happersett, 88 U.S. (21 Wall.) 162 (1874).

191. 88 U.S. (21 Wall.) at 165-67.

192. 88 U.S. (21 Wall.) at $165,170$.

193. U.S. CoNST. art. IV.

194. 88 U.S. (21 Wall.) at 171.

195. 88 U.S. (21 Wall.) at 175. 
the fifteenth amendment probably confirmed the worst fears of those feminists who had opposed the fourteenth amendment and attempted to revise the fifteenth amendment. Women were only vaguely protected by the Constitution, and that protection could easily be negated. 196

Neither counsel nor the Court in Minor questioned whether a classification by sex, of individuals acknowledged to be citizens and persons under the Constitution, violated the equal protection of the laws. The Court was more interested in the nature of the interest that had been affected than in the nature of the classification creating the inequality under the law.

After Minor and the Slaughter-House Cases, federal and state courts, drawing, however ineptly, on the natural law vision of the fourteenth amendment, came to pay new attention to the types of substantive interests protected by that amendment in the last years of the nineteenth century, relying on the due process clause and not the privileges and immunities clause. As Justice Holmes concluded, judges began with "an unpretentious assertion of the liberty to follow the ordinary callings" and then expanded that "innocuous generality ... into the dogma [of] Liberty of Contract." 197 That is, it is one thing to forbid the states from limiting a profession to named individuals and quite another to forbid them from regulating a profession to achieve a public purpose. ${ }^{198}$ In this era of substantive due process, the courts struck down many laws on the theory that they unconstitutionally interfered with a person's freedom to enter into contracts.

The development of substantive due process doctrine raised a novel issue relating to classifications by sex. If persons were entitled to the protections of due process of law, including the liberty to contract, and if women were persons, on what basis might women be subject to greater restrictions on their freedom to contract than men? ${ }^{199}$ Though the analysis could easily have been framed in equal protection terms, courts declined to proceed in this manner, for they were chiefly concerned with the elaboration of freedom of contract. Statutes discriminating on the basis of sex were rarely attacked prior to 1900 , and such attacks usually failed. ${ }^{200}$ In Holden $v$. Hardy, ${ }^{201}$ upholding a Utah law

196. See generally Crozier, Constitutionality of Discrimination Based on Sex, 15 B.U. L. REV. 723 (1935).

197. Adkins v. Children's Hosp., 261 U.S. 525, 568 (1923) (Holmes, J., dissenting). See generally Forbath, supra note 170.

198. See also Barbier v. Connolly, 113 U.S. 27 (1885). See generally Forbath, supra note 170; Kay, supra note 15 , at 681-86, 701-05.

199. D. KIRP, M. Yudof \& M. Franks, supra note 111, at 118. A similar analysis of the race cases in the progressive era has been undertaken by President Benno Schmidt of Yale. See Schmidt, Principle and Prejudice: The Supreme Court and Race in the Progressive Era, Part I: The Heyday of Jim Crow, 82 ColuM. L. Rev. 444 (1982).

200. But see Ritchie v. Illinois, 155 Ill. 98, 40 N.E. 454 (1895); People v. Williams, 189 N.Y. 131, 81 N.E. 778 (1907). Ritchie, a case decided in 1895 under the due process clause of the 
that limited the work day of miners, the Supreme Court noted in passing that many states had enacted laws restricting the hours of employment of women and children: "[w]hile their constitutionality, at least as applied to women, has been doubted in some of the States," wrote the Court, "they have been generally upheld."202

As previously noted, Lochner v. New York, ${ }^{203}$ decided in 1905 by the U.S. Supreme Court, marked the high-water mark of the era of substantive due process. A bare majority of the Justices struck down a law prohibiting the employment of bakers for more than ten hours a day or sixty hours a week. The New York law interfered with the liberty of persons to make contracts, the Court reasoned: "There is no contention that bakers as a class are not equal in intelligence and capacity to men in other trades or manual occupations, or that they are not able to assert their rights and care for themselves . . ."204 When Lochner is read in tandem with Holden, the clear implication is that women are incapable of protecting their own interests and appropriately are treated as wards of the state, ${ }^{205}$ a proposition made explicit three years later in Muller v. Oregon. ${ }^{206}$ A unanimous Court in Muller embraced the proposition that sex is a permissible basis for differentiation, upholding a maximum-hours law applied only to women. ${ }^{207}$

Some thoughtful critics have applauded Muller. Constitutional

Illinois Constitution, demonstrates that a contrary view was taken by some courts after the decision in Bradwell, some 22 years earlier. In 1893, the Illinois legislature had enacted a law prohibiting women, whether adults or minors, from working for more than eight hours a day in any factory or workshop manufacturing clothing or wearing apparel. There were at least eight challenges to the law within a two-year period (apparently all brought by male employers), and the Illinois Supreme Court declared the law unconstitutional. The state argued that the law was "designed to protect woman on account of her sex and physique." 155 Ill. at 111, 40 N.E. at 458. The court appeared none too impressed with any law, even one of general application, that sought to protect people from harmful employment. 155 IIl. at 115,40 N.E. at 459 . But the court went further. It cited Minor for the proposition that women were citizens and persons, as fully protected as men by the due process clause of the fourteenth amendment. 155 Ill. at 112, 40 N.E. at 455 . Moving to the Illinois state constitution, the court held that women were entitled to the same rights "to make contracts with reference to [their] labor as are . . men":

The law accords to her, as to every other citizen, the natural right to gain a livelihood by intelligence, honesty and industry in the arts, the sciences, the professions or other vocations. Before the law, her right to a choice of vocations cannot be said to be denied or abridged on account of sex.

155 Ill. at 111-12, 40 N.E. at 458 (citation omitted).

The Ritchie decision did not-reflect the prevalent judicial attitude toward special labor legislation for women in the late nineteenth and early twentieth centuries. Ritchie itself was overruled. Ritchie v. Wayman, 244 Ill. 509, 91 N.E. 695 (1910). See also Wenham v. Nebraska, 65 Neb. 394, 91 N.W. 421 (1902); Commonwealth v. Hamilton Mfg. Co., 120 Mass. 383 (1876).

201. 169 U.S. 366 (1898).

202. 169 U.S. at 395.

203. 198 U.S. 45 (1905).

204. 198 U.S. at 57.

205. See G. Gunther, Constitutional Law 456 n.6 (11th ed. 1985).

206. 208 U.S. 412 (1908).

207. See D. KIRP, M. YUdOF \& M. FRANKS, supra note 111, at 118-19. 
scholar Gerald Gunther has suggested that Lochner erred in accepting "inequalities of fortune," denying the legitimacy of state efforts to redress such inequalities; he regards Muller a happy exception to such judicial insensitivity. ${ }^{208}$ I disagree. Muller undermines the concept of equality under law, as embodied in the fourteenth amendment and in antebellum state court decisions. Depending on their skills and opportunities, bakers may choose a less dangerous profession or evade a state-imposed limit on working hours. A woman cannot escape her sex, for her options have been circumscribed on the basis of an unalterable personal characteristic. The law affirmed in Muller embodied a close-ended status distinction of precisely the sort that should be impermissible under the fourteenth amendment. A Court intent upon preserving liberty and individual autonomy and advancing the public welfare, while allowing legislatures to redress liberty-constricting inequalities of bargaining power, should have upheld the Lochner law and overturned the Muller statute.

The Supreme Court reaffirmed Muller in 1915, upholding a maximum-hour law applicable only to women. ${ }^{209}$ But eight years later, in Adkins v. Children's Hospital, 210 the Justices struck down a federal act fixing minimum wages for women in the District of Columbia. The Court declared that the statute was "a naked, arbitrary exercise of power that . . . cannot be allowed to stand under the Constitution of the United States."211 The Adkins majority had to chart a course through a treacherous array of precedents. By 1923, the Court had repudiated Lochner without expressly overruling it, ${ }^{212}$ and hence the Adkins Court could not rely heavily on Lochner. Instead, it chose to undermine Muller.

The majority opinion in Adkins strongly endorses the equality of women under the law. The tenor of that opinion is that women had come a long way since the dark days of Muller. ${ }^{213}$ The "ancient inequality of the sexes, otherwise than physical," says the Court, "has continued with 'diminishing intensity." "214 While physical differences "must be recognized in appropriate cases," the Court notes, in language reminiscent of that of Herbert Spencer, that it could not endorse the notion that mature women were less capable than men of making

208. Gunther, The Supreme Court, 1971 Term - Foreword: In Search of Evolving Doctrine on $A$ Changing Court: $A$ Model for a Newer Equal Protection, 86 HARv. L. REV. 1, 42 (1972).

209. Miller v. Wilson, 236 U.S. 373 (1915); see also Hawley v. Walker, 232 U.S. 718 (1914) (per curiam); Riley v. Massachusetts, 232 U.S. 671 (1914).

210. 261 U.S. 525 (1923). See D. KIRP, M. YUdof \& M. FRANKS, supra note 111, at 119-20.

211. 261 U.S. at 559.

212. See G. GuNTHER, supra note 205, at 459; see also Bunting v. Oregon, 243 U.S. 426 (1917); Adkins v. Children's Hosp., 261 U.S. 525, 563-64 (1923) (Taft, C.J., dissenting).

213. See D. KIRP, M. YUDOF \& M. FRANKS, supra note 111 , at 119.

214. 261 U.S. at 553. 
contractual decisions for themselves. ${ }^{215}$ The trend of modern legislation, "as well as that of common thought and usage," is that women should be emancipated from laws according them special protections or restraining their contractual and civil relationships. ${ }^{216}$ Since Muller, "revolutionary" changes in the "contractual, political and civil status of women," had occurred, and thus "it is not unreasonable to say that these differences have now come almost, if not quite, to the vanishing point."217 The culmination of this revolution was the adoption, in 1920, of the nineteenth amendment, extending suffrage to women.

Adkins advances the proposition that women are entitled to constitutional protection under the fourteenth amendment. Although the opinion is not couched in the language of equal protection, ${ }^{218}$ its observations are relevant to equal protection analysis. Women are no less capable than men of making life choices for themselves, and allegedly protective legislation can be hurtful.

The reliance by the Adkins court on the nineteenth amendment is well placed. That amendment specifies that the rights of "citizens" to vote may not be abridged on the basis of sex, thus presuming that women were already citizens under the Constitution. It reflects the changes in the status of women that had occurred since the early nineteenth century, extending that trend by removing the greatest remaining obstacle to women's emancipation, their disenfranchisement. In so doing, it symbolically confirms the view that at least one historical understanding of equality under the law is inconsistent with statutes that routinely sort individuals on the basis of their sex.

Adkins, whether a symbol of liberty for women or a misbegotten judicial assault on legislation protecting workers, could have provided the starting point for modern fourteenth amendment analysis of sex discrimination, connecting older conceptions of liberty, citizenship, and equality under law, with more modern sensitivities to unfairness based on sex discrimination. This did not occur, however, for the Supreme Court subsequently ignored Adkins; fifty years later, when the Court drew on the fourteenth amendment to strike down sex-based distinctions, Adkins went unmentioned. ${ }^{219}$

The neglect of Adkins is entirely understandable. For one thing, sex discrimination was not a serious concern of the Supreme Court in 1923, despite the Adkins opinion. At least three of the newest members of the Court were anxious to resurrect and extend the Lochner substantive due process approach. Adkins inaugurated a brief period

215. 261 U.S. at 553.

216. 261 U.S. at 553.

217. 261 U.S. at 553.

218. See Morehead v. New York, 298 U.S. 587 (1936) (substantive due process).

219. See Reed v. Reed, 404 U.S. 71 (1971). 
of heightened scrutiny of federal and state interference with freedom of contract: ${ }^{220}$ sex discrimination was an ancillary concern. For another, Adkins marked only a "temporary" victory for equality of the sexes. As Blanche Crozier, an early student of women's constitutional rights, observed: "It does not appear that at any time since the adoption of the Constitution has discrimination based on sex been unconstitutional."221 Adkins itself supports this reading.

The Adkins majority attempted to breathe new life into the Lochner rule "forbidding legislative interference with freedom of contract."222 The Court came to regard Adkins as a substantive due process case, not as a sex discrimination case. In Wolff Co. v. Industrial Court, ${ }^{223}$ for example, decided only a month after Adkins, the majority cites the case for the proposition that "[w]hile there is no such thing as absolute freedom of contract and it is subject to a variety of restraints, they must not be arbitrary or unreasonable. Freedom is the general rule, and restraint the exception. The legislative authority to abridge can be justified only by exceptional circumstances."224 Nor did the Court extend Adkins to other areas of sex discrimination; instead, it resurrected Muller. In Radice v. New York, ${ }^{225}$ decided a year after Adkins, the Court upheld a state law prohibiting women from night work in restaurants.

Only the narrow holding of Adkins survived its subsequent elaboration. And Adkins itself did not endure. Less than a year after reaffirming Adkins in Morehead v. New York, ${ }^{226}$ the Court overruled both decisions in one of the great New Deal turnabouts, upholding a minimum-wage law applicable only to women.227 Freedom of contract was not expressly guaranteed under the fourteenth amendment, the Court asserted in West Coast Hotel v. Parrish, and "regulation which is reasonable in relation to its subject and is adopted in the interests of the community is due process."228 Adkins incorrectly departed from these principles, and the state might properly consider that women as a class receive the least pay, have less bargaining power with employers, and "are the ready victims of those who would take advantage of their necessitous circumstances."229

220. See generally E. CORWIN, THE CONSTITUTION OF THE UNITED STATES OF AMERICA: ANALYSIS AND INTERPRETATION 1321-26 (1973).

221. Crozier, supra note 196, at 745.

222. Adkins v. Children's Hosp., 261 U.S. 525, 550, 554 (1923).

223. 262 U.S. 522 (1923).

224. 262 U.S. at 534; cf. Morehead v. New York, 298 U.S. 587 (1936) (fair wage law for women violates due process clause of fourteenth amendment).

225. 264 U.S. 292 (1924); see D. KIRP, M. YUDOF \& M. FrANKS, supra note 111, at 119-20.

226. 298 U.S. 587 (1936).

227. West Coast Hotel v. Parrish, 300 U.S. 379 (1937).

228. 300 U.S. at 391.

229. 300 U.S. at 398; see also D. KIRP, M. YUDoF \& M. FRANKS, supra note 111, at 120. 
The idea of equality under the law for women, its wagon hitched to the star of substantive due process, collapsed as that star fell. The Court was pressed to approve the social and economic legislation of the New Deal and used the West Coast Hotel case for this purpose. At a moment of apparent institutional crisis, the Justices were in no mood for refined distinctions among cases relying on a discredited doctrine. ${ }^{230}$ Lochner and Adkins were lumped together, symbols of the judicial heresy of applying substantive due process in the economic domain. Adkins has never again been cited in a sex discrimination case.

In the 1948 Goesaert case, ${ }^{231}$ the Supreme Court upheld against equal protection challenge a Michigan law prohibiting a woman from being licensed as a bartender unless she was " the wife or daughter of the male owner' of a licensed liquor establishment."232 Goesaert marked the first time that the Supreme Court was faced with the contention that a sex-based distinction violated the equal protection clause; it did not treat the moment with great seriousness. In a jocular three-page opinion, the majority speaks of "the alewife, sprightly and ribald, in Shakespeare," and notes that "[ $t]$ he Fourteenth Amendment did not tear history up by the roots."233

Goesaert blinks at the history of equality under the law.234 "It would be an idle parade of familiar learning" to review the relevant equal protection precedents, says the opinion. ${ }^{235}$ The Court forgets that the equal protection clause applies to "any person", it does not speak of the antebellum history of equality under the law, and it ignores the resolution of these concerns in Adkins, a case that could well have been given new life in equal protection garb. ${ }^{236}$

When sex discrimination cases again found their way to the Supreme Court in the 1970s, the historical underpinnings of the constitutional claims had been lost. The conception of equal protection as centered on equality under law was obscured by a philosophical and ideological fixation on "suspect" classifications. The predictable out-

230. See generally Benedict, supra note 45.

231. Goesaert v. Cleary, 335 U.S. 464 (1948). See D. KIRP, M. Yudof \& M. FRANKS, supra note 111 , at 120 .

232. 335 U.S. at 465 .

233. 335 U.S. at 465 .

234. In fairness to the majority, it is not entirely clear whether the Court was lightly dismissing any claim of sex discrimination under the equal protection clause, or whether it was simply affirming the traditional authority of the states, embodied in the twenty-first amendment, to regulate the liquor trade. See, e.g., California v. LaRue, 409 U.S. 109 (1972). Indeed, the state's brief in Goesaert argued that "while discriminations against women as such are invalid, discriminations against them in matters relating to intoxicating liquors have consistently been upheld." Brief for Appellees at 23, Goesaert v. Cleary, 335 U.S. 464 (1948).

235. 335 U.S. at 467.

236. Indeed, the Court opined that the equal protection claim of women is entirely novel, reflecting new "sociological insight[s]" and "shifting social standards." 335 U.S. at 466. 
come was judicial confusion: "A nation that desiccates its history in the course of extracting and studying its law risks feeding itself pap." 237

What should we make of the disunity of the equal protection clause, of the multiple traditions upon which it was based, and of the conflicts among visions of equality under law? Obviously we should be skeptical of any unifying or monolithic concept that purports to subject all cases to a single standard. There should be no assumption that equal protection applies only to racial and ethnic classifications (p. 163), that all economic classifications are permissible (p. 200), or that only the powerless need apply for equality under law. The more encompassing the theory, the more likely that it does not reflect the diverse origins of the equal protection clause.

There should also be a realization that the multiple historical strands are reflected in the modern debates over equal protection theories, allowing each warring camp to find solace in the nineteenth-century record. For example, devotees of fundamental rights analysis, urging that inequalities with respect to certain vitally important interests (e.g., voting, interstate travel, education) require a compelling governmental justification, may seek support in the natural law background of the equal protection clause. Where those natural or fundamental rights come from, whether they derive only from the text or structure of the Constitution, how they are limited, what the role of courts should be in articulating them: these are all difficult questions - but questions well within the natural law tradition of the clause.

Similarly, the Jacksonian concept of equal protection, with its emphasis on avoiding discrimination against classes, and the race-specific radical Republican version of equal protection, with its emphasis on protecting the civil rights of African-Americans, also find strong support in history; the former, as I have attempted to demonstrate, has particularly significant implications for the constitutionality of sex discrimination. From this perspective, the debate between those who emphasize immutability of class characteristics and those who emphasize powerlessness and isolation from the normal political processes is entirely understandable, for both images of equality are reflected in the mirror of equal protection. They attempt to extrapolate from two historical concepts: the paradigm case of racial discrimination and the antebellum hostility to special laws and class legislation.

The multiple dimensions of the equal protection clause also give us some insight into the disarray and chaos in equal protection doctrine

237. H. Graham, supra note 14, at 248; see also White, Law as Language: Reading Law and Reading Literature, 60 TEXAS L. REV. 415 (1982). 
between the Slaughter-House Cases in 1873 and the end of the substantive due process era during the New Deal, a disarray that to some extent is still with us. One should begin with the understanding that the framers of the fourteenth amendment were not perfect artisans of legal principles, that they did not consider the many permutations of their concepts of liberty and equality, and that their principles, as is true for all mortals, were often in conflict. They were, first and foremost, politicians savoring the fruits of victory (pp. 110-11, 143).

But a theory of equal protection should not be rejected simply because there are hard cases or ambiguities (p. 177). The closed nature of a classification or its reliance on immutable characteristics, for example, may well undergird some concepts of equal protection, though few would claim that a profoundly retarded person has a constitutional right to a government job as a nuclear physicist. In general, laws focusing on named individuals may be impermissible, but occasionally there may be a legitimate class of one. Abstract principles, particularly when they conflict, cannot eliminate the need for judgment.

Once we abandon the idea that the framers were perfect, if only the interpreters were more attentive to their revealed purposes, it follows that some doctrinal disarray is inevitable. For example, Justice Field tried to the best of his ability, which was considerable, to distinguish between privilege and class favoritism, and necessary and reasonable regulation of economic affairs (pp. 172-74). But even he had trouble, on many occasions, discerning the difference - particularly with increasing industrialization and state efforts to protect workers. As Professor Kay notes, this Jacksonian distinction tended to collapse and a boundless search for reasonableness - what pleased the Justices. was substituted in its place. ${ }^{238}$ This approach came to be identified with the now-repudiated era of substantive due process.

Once the era of substantive due process came to an end and equal protection became the primary framework for analysis, the judicial focus came to be upon motivation as a means of distinguishing between unconstitutional laws that create privilege or discriminate against identifiable classes and laws that were permissible, though they might have side-effects that benefited or harmed particular individuals and classes. Doctrines of constitutional motivation may be viewed as a way of reconciling Jacksonian democratic principles with the necessities of the modern, bureaucratized welfare state. If such approaches appear inadequate, the problem may lie as much with the inadequacy of the multiple visions embodied in the equal protection clause as with our own lack of perception as interpreters of the past.

For all the advantages of recognizing the disunity of the concept of 
equal protection, there also are sirens that may lead us dangerously astray. Some constitutionalists may succumb to temptation, believing that a cornucopia of visions justifies nearly any judicial result, that there is no such thing as a right or wrong result under the equal protection clause. But scholars and courts should think long and hard before fashioning an equal protection clause out of such malleable material, retreating to the utter subjectivity of one equal protection clause for each interpreter. There is much ground, high ground, between an oversimplified unitary theory of equal protection and the infinite unpredictability and chaos of complete subjectivity. Constitutionalists should urgently seek that high ground, and we are indebted to Professor Nelson for providing the historical analysis to nurture their efforts. 